\title{
norden
}

\section{Plastic value chains}

Case: WEEE (Waste Electric and electronic equipment) in the Nordic region

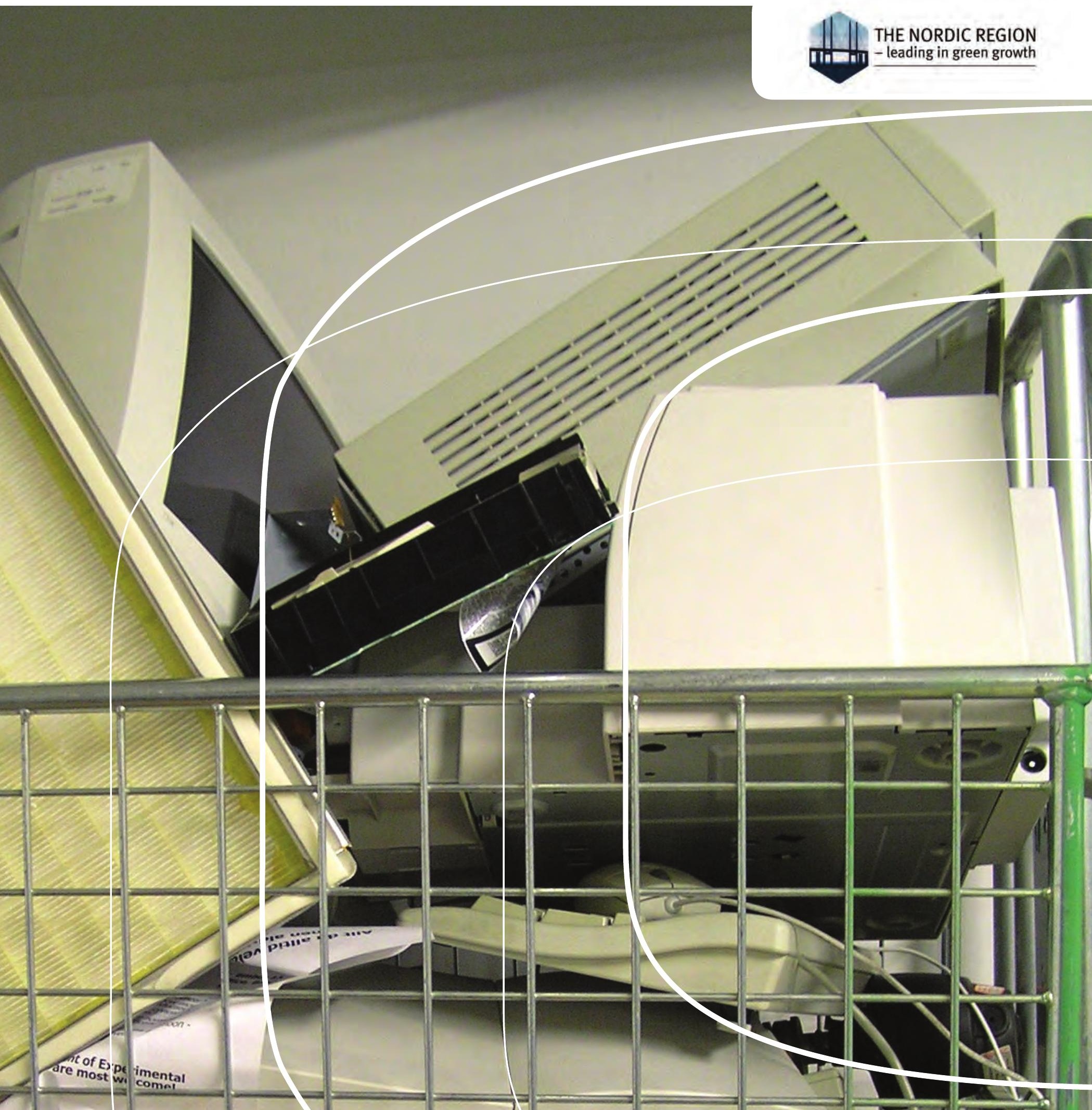



4 norden 



\section{Plastic value chains}

Case: WEEE (Waste Electric and electronic equipment) in the Nordic region

John Baxter, Margareta Wahlstrom, Malin Zu Castell-Rüdenhausen, Anna Fråne, Malin Stare, Søren Løkke and Massimo Pizzol 
Plastic value chains

- Case: WEEE (Waste Electric and electronic equipment) in the Nordic region

John Baxter, Margareta Wahlstrom, Malin Zu Castell-Rüdenhausen, Anna Fråne, Malin Stare, Søren Løkke and Massi-mo Pizzol

ISBN 978-92-893-2802-9

ISBN 978-92-893-2803-6 (EPUB)

http://dx.doi.org/10.6027/TN2014-542

TemaNord 2014:542

ISSN 0908-6692

(C) Nordic Council of Ministers 2014

Layout: Hanne Lebech

Cover photo: ImageSelect
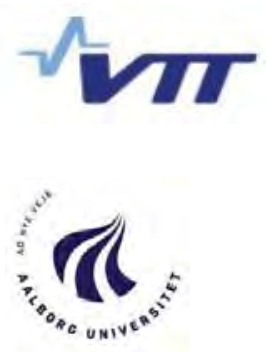

This publication has been published with financial support by the Nordic Council of Ministers. However, the contents of this publication do not necessarily reflect the views, policies or recommendations of the Nordic Council of Ministers.

\section{www.norden.org/en/publications}

\section{Nordic co-operation}

Nordic co-operation is one of the world's most extensive forms of regional collaboration, involving Denmark, Finland, Iceland, Norway, Sweden, and the Faroe Islands, Greenland, and Åland.

Nordic co-operation has firm traditions in politics, the economy, and culture. It plays an important role in European and international collaboration, and aims at creating a strong Nordic community in a strong Europe.

Nordic co-operation seeks to safeguard Nordic and regional interests and principles in the global community. Common Nordic values help the region solidify its position as one of the world's most innovative and competitive.

\section{Nordic Council of Ministers}

Ved Stranden 18

DK-1061 Copenhagen K

Phone (+45) 33960200

\section{www.norden.org}




\section{Content}

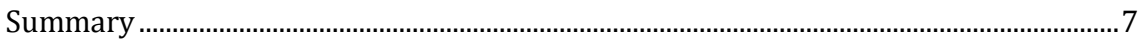

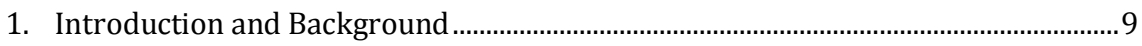

2. The Nordic WEEE plastics project.............................................................................. 11

2.1 The Project Consortium ……….................................................................... 11

2.2 Project Activities.................................................................................................. 11

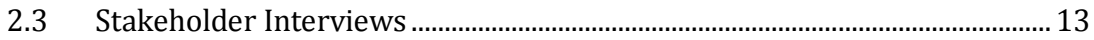

2.4 Project Workshop................................................................................................ 16

3. Nordic WEEE plastics: the current situation ........................................................ 17

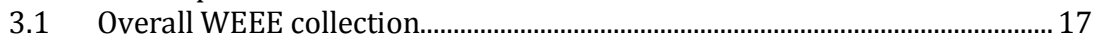

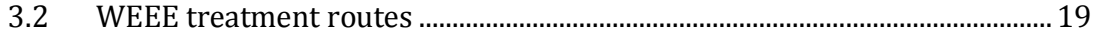

3.3 Plastics in WEEE ................................................................................................. 21

3.4 Treatment of WEEE plastics ............................................................................ 22

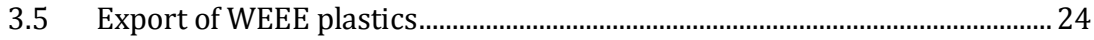

3.6 Losses from collection, sorting and storage of WEEE ...................................... 25

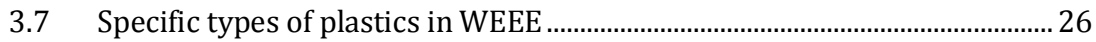

3.8 End-use markets for recycled WEEE plastics.................................................... 31

3.9 The current situation: summary ......................................................................... 34

4. Obligations and impact of relevant legal and regulatory frameworks..................... 37

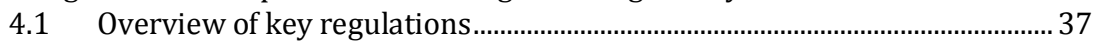

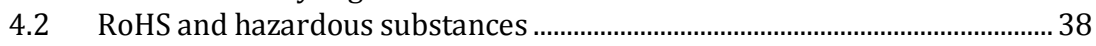

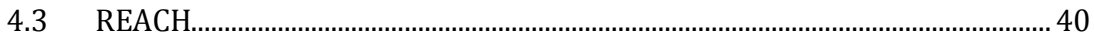

4.4 End-of-Waste criteria............................................................................... 41

5. Specific product focus: Small Domestic Appliances ................................................ 45

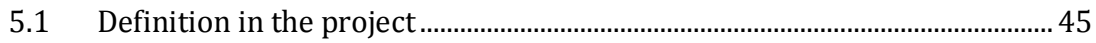

5.2 Challenges presented by SDAs....................................................................... 47

6. Routines, standards and technologies for sorting within Europe and the

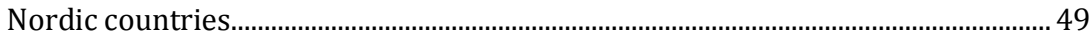

6.1 General scope of the issues ............................................................................. 49

6.2 Pre-processing of WEEE plastics streams .................................................... 51

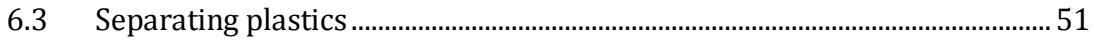

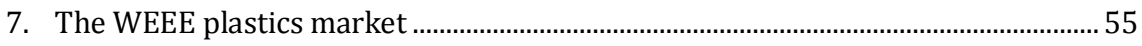

7.1 Collection and Recycling of WEEE: EPR systems........................................... 55

7.2 WEEE Plastics: Knowledge, Information and Competence ............................ 58

7.3 WEEE Plastics: Market Conditions....................................................................... 59 


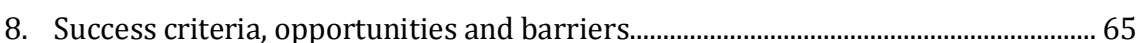

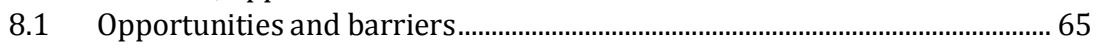

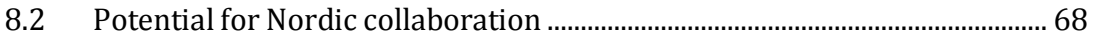

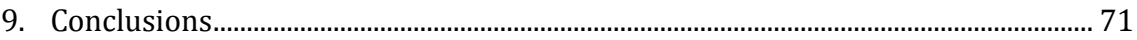

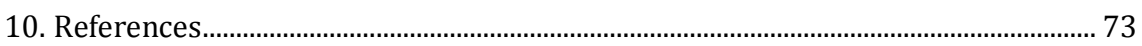

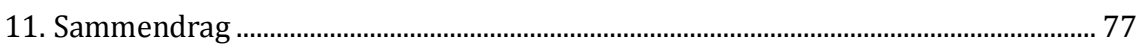

12. Annex A: Reference / Stakeholder Groups................................................................. 79

13. Annex B: Meeting Notes from Nordic Workshop........................................................ 81

13.1 Parallel sessions - Project 2 …................................................................... 81 


\section{Summary}

This report is the primary outcome from Part I of the project "Nordic plastic value chains, Case WEEE (Waste Electric and Electronic equipment)" initiated by the Nordic Waste Group (NAG). The report for Part 2 will be published in December 2014. The report assesses the current WEEE plastics value chain in the Nordic region, and finds that whilst important facts remain unclear, current practice in the region is worldleading yet has further scope for improvement. About 400,000 tonnes of WEEE is collected in the Nordics each year, of which about 70,000 tonnes is plastic. The project estimates that well under 20,000 tonnes of this plastic is currently recycled. Small Domestic Appliances (SDAs), which are the focus of the project, account for 188,000 tonnes of WEEE and 38,000 tonnes of plastic collected, mostly acrylonitrile butadiene styrene, polystyrene and polypropylene. Hazardous materials - metals and, to a greater extent, brominated flame retardants, are problematic in WEEE plastics. TVs and monitors are the most prevalent sources of hazardous materials.

The plastics mix is relatively separable - the technologies appear well-established, however the necessary capital expenditure is considerable. Large throughputs are required, thus representing a barrier to market entry. In principle there are deep end-use markets for recycled WEEE plastics, but the picture in practice is more difficult. Near closedloop recycling potential is currently very limited and the marketplace for recycled plastics is competitive. Concerns include quality issues and worries about hazardous materials and effective competition with other, more mature, recycled plastics sources such as packaging waste.

The relevant regulatory frameworks include the WEEE, RoHS and REACH directives, and the (draft) EU end-of-waste criteria for plastics. For the most part these impose moderate costs (for treatment) that should be recoverable given viable markets for the recycled plastics.

Market factors are recognised as being of primary importance. The market is divided in different ways at different parts of the value chain. Collection and transport of waste is a relatively competitive / diffuse market, but treatment of plastic waste is much less so. Market division is good for maintaining downward pressure on costs / prices, but less so for quality. Perhaps the single most important issue is one of the most difficult - to 
engage electronics manufacturers in a meaningful fashion. Perhaps through the offering of subsidies, establishing certification frameworks and/or looking at public sector procurement policies, governmental organisations can have a real influence on this tricky problem.

The report is part of the Nordic Prime Ministers' green growth initiative: "The Nordic Region - leading in green growth." Read more in the web magazine "Green Growth the Nordic Way" at www.nordicway.org or at www.norden.org/greengrowth 


\section{Introduction and Background}

This report presents the results of Part I of the Nordic project: "Nordic plastic value chains Case WEEE (waste electric and electronic equipment)."

The project is part of the Nordic Prime Ministers' green growth initiative, "The Nordic Region - leading in green growth". The initiative identifies eight priorities aimed at greening the Nordic economies, one of which is to develop innovative technologies and methods for waste treatment.

To realise the Prime Ministers' vision, the Nordic Waste Group (NWG) launched an initiative titled "Resource Efficient Recycling of Plastic and Textile Waste," comprising of six projects aimed at identifying ways in which the reuse and recycling of plastic and textile waste can be in-creased. Three of them, including the subject of this report, concern improved recycling of plastic waste.

The aim of this project is to provide an overview of the WEEE plastic waste situation in the Nordic countries, with a view to proposing improvements along the value chain. This forms part of the Green Growth initiative of the Nordic Council of Ministers, via the working group NAG (The Nordic Waste Group). It is one of three plastics recycling projects within the Waste part of that Initiative.

The overall aims of the project are to:

- identify, document and analyse existing practice for plastics in WEEE (waste electrical and electronic equipment)

- assess relevant legal, regulatory, economic and practical drivers for effective recycling of WEEE plastics

- suggest practical measures that might serve to develop and improve practice.

The eventual output of the project will be a guide for improvement and optimisation of the value chains.

This report presents estimates of the amount of WEEE and plastics in WEEE in the Nordic countries, as well as the current treatment routes. Relevant policies, practices, market conditions and technologies are reviewed and summarised. Potential routes for improvements to the value chains are given, with a view to further investigation in Part II of 
the project. A particular focus on plastics recycling from small domestic electronic devices is established.

The potential hazardousness of plastic materials from WEEE is established as a critical issue. In addressing this, the project and report should inform other plastics value chains where hazardous substances present significant issues.

The main target groups for the proposed results are policy makers and stakeholders in the Nordic countries, such as national and local authorities, relevant non-governmental organisations, private and public waste operators, trade and business organisations and the broader public.

The project is a collaborative effort between partners based in Norway, Sweden, Denmark, Finland and Iceland. 


\section{The Nordic WEEE plastics project}

\subsection{The Project Consortium}

The following organisations across the Nordic region form the project consortium:

- Ostfold Research (Østfoldforskning), Norway - project manager.

- IVL (Swedish Environmental Research Institute).

- VTT (Technical Research Centre of Finland).

- Aalborg University, Denmark.

- Environice, Iceland.

The project began in June 2013. Part I of the project described in this report scopes and investigates the problem. Recommendations for improvements will be developed in Part II, and presented in the final project report, at the beginning of 2015 .

\subsection{Project Activities}

There follows a summarised list of the primary activities in Part I of the project, as outlined in the proposal. The outputs from these activities are described in the following chapters.

- Activity 1 - Describing the Nordic WEEE plastics market

The output from this Activity is described in Chapter 3 below. Statistical data on WEEE as a whole, from national registers and statistics, is gathered and analysed. The plastics content of WEEE and of specific product types are assessed, and this data is combined to give an overview of the WEEE plastic streams, relating to specific products, across the Nordic region. Losses of WEEE are assessed, along with data on imports and exports of products and of waste. The activity also summarises and analyses the end-use markets for recycled WEEE plastics. 
- Activity 2 - Specific EE product groups as a focus.

Discussion at the first project workshop led to a decision to focus the project on Small Domestic Appliances. These are regarded to be the most challenging WEEE products, not least because of their hazardous material content. Issues extend from collection, through disassembly, metals recovery, plastics treatment and recycling. Specific challenges relating to SDAs are addressed within Chapter 5 below.

- Activity 3 - Establish a reference group with representatives along the value chain.

Representatives from extended responsibility organisations across the Nordic region, WEEE and plastics recyclers, and other interested stakeholders were invited to form the project reference group. In addition, a number of stakeholders and interested parties provided input via the joint workshop for the three plastics projects, held in Oslo in November 2013. These stakeholders are listed in Annex A.

- Activity 4 - Conduct interviews with reference group members and other stakeholders.

Further details on this activity can be found later in this Chapter. The inputs from stakeholders - both formal and informal - form the basis for most of the work in the following chapters.

- Activities 5 and 6 - Assess obligations and impact of relevant legal and regulatory frameworks.

The output from these Activities can be found in Chapter 4 below. The relevant frameworks include the WEEE Directive, the REACH regulation, the RoHS directive and the Waste Framework Directive. The latter establishes the End-of-Waste criteria specific to Activity 6.

- Activity 7 - Assess routines, standards and technologies for identifying and sorting within Europe and the Nordic region.

The output from this Activity can be found in Chapter 6 below. The Activity focuses mostly on the technological challenges relating to WEEE plastics recycling. 
- Activity 8 - Assess market opportunities for WEEE plastics fractions.

The output from this Activity can be found in Chapter 7 below. Marketrelated issues are found to be an essential complement to technological, social and political factors in developing WEEE plastics recycling practice in the Nordic region.

Under the umbrella of these activities, the information and data in this report was gathered between June 2013 and January 2014. The main source of information have been:

- Literature sources.

- Interviews with key stakeholders across the Nordic region.

- Input from other stakeholders via the Project Workshop, held in Oslo in November 2013.

- Personal experience and expertise of the project partners.

\subsection{Stakeholder Interviews}

Two groups of stakeholders - which overlapped to some degree - were established throughout the autumn of 2013. The first was a reference group, who were targeted for formal interview within the project. The second were the interested parties that attended the project workshop. Valuable inputs were obtained from both groups, and these are a central element of the findings outlined in the following Chapters. Here we will concentrate on the formal interview stage.

It was decided by the project group at an early stage not to impose a detailed structure on the interviews. This was for a number of reasons, including flexibility in the use of local languages or English as appropriate, an early finding from several interviewers that respondents seemed more comfortable responding in a fairly unstructured fashion, and that different stakeholders had different levels of expertise in different issues. Nevertheless, a broad set of topics was suggested by one interviewer and seen by others; see below.

Numerous stakeholders were concerned with issues of anonymity and confidentiality, and only prepared to give input on an anonymous basis. All of the input that forms part of the later Chapters is provided on this basis, and in synthesised form. The interviews were conducted by the following members of the project team: 
- Norway: Kari-Anne Lyng, Østfoldforskning.

- Sweden: Malin Stare, IVL.

- Denmark: Massimo Pizzol, Aalborg University.

- Finland: Malin Meinander, VTT.

- Iceland: Stefan Gislason, Environice.

Sixteen stakeholders gave formal interview input in greater or lesser depth. They are broadly classified along the WEEE plastics value chain as follows:

- Six interviewees were representatives of NGOs or organisations responsible for Extended Producer Responsibility.

- Seven interviewees were representatives of recycling companies.

- One interviewee was a consultant with wide-ranging sector experience.

- One interviewee was a representative of an industrial sector organisation.

- One interviewee was an importer of electronic equipment.

Many more stakeholders were initially contacted. Each project team member reported difficulties in recruiting interviewees, particularly at relatively short notice as the time scale of the project demanded. A number of stakeholders indicated their willingness to participate but only at a later stage. Others could not find time in their schedule, or expressed reluctance to contribute for fear of being identified and/or divulging commercially significant information. Considering the project outline and proposal, much of the value chain is well covered by stakeholders that have already provided input. Presently, the least complete coverage relates to producers / importers of electronic equipment, particularly those with the potential to influence design considerations. Part II of the project brings this part of the value chain into greater focus and additional stakeholders will be sought within this part of the project.

One interviewer produced a broad outline of questions / topics that they covered with their interviewees. This was shared with the other interviewers, but it was left to individuals to decide the degree to which the outline was followed. Six broad topics were identified, relating to the interviewee's experience and opinion on: WEEE and recycling as a whole; strengths and weaknesses of the existing collection and recycling systems for WEEE in their national territory area; plastic in e-waste and its value chain; the efficiency of WEEE-plastic recycling; hazardous sub- 
stances in WEEE-plastic; the potential for Nordic cooperation on WEEEplastics recycling.

The following more detailed list of questions was developed at an earlier stage, but was intended as a general pointer rather than a list to be specifically asked. Interviewers made specific use of this list to differing degrees:

- Is there any data for your region about the amount of plastics in WEEE in total?

- Is there any data for your region about the fraction of plastics in WEEE?

- What are the main types of plastic in WEEE in your region?

- What are the recycling rates for WEEE in your region? And for the plastics fraction of WEEE?

- What system is in place for collection and treatment/management of WEEE in your region? Is it an EPR system? Can you describe how the system functions and what incentives are in place to achieve this (political, financial, regulatory)? What end-use markets are there for recycled WEEE plastics? Where are the revenue streams for these?

- How many companies are involved in collecting and treatment/management of WEEE in your region? Is there an open market/competition situation in your region, or a monopoly?

- Is there a form of WEEE register in your region, where data on WEEE can be found?

- How do the different collectors report how much they have collected of which WEEE fractions and to whom?

- Do the municipal waste management authorities have responsibility for any WEEE collection and treatment in your region?

- How do the different treatment/management companies report how much they have treated of which WEEE fractions and to whom?

- How are losses of WEEE reported, or estimated in your region?

- How much WEEE waste is stolen/lost from the system in your region?

- Are there any private initiatives, or charitable initiatives to collect WEEE in your region?

- How is the WEEE collection and treatment system in your region financed? 
- What are the main routes that the collected WEEE take from your region to treatment? Can you provide some sort of flow sheet summarizing the main flows and transport routes?

- Are there any specific rules, or regulations in place governing hazardous substance content in WEEE plastics that can be recycled? (e.g. in Norway there is a ban on recycling brominated flame retardants). If any such rules or regulations are in place, what knowledge is available about how the treatment companies ensure that this is enforced?

\subsection{Project Workshop}

A joint Project Workshop for all three plastics projects, organised by SIGLA and IVL, was held in Oslo in November 2013. Over 50 stakeholders took part in a wide-ranging day of exercises and discussions on key issues relating to the three plastics waste recycling projects. 


\section{Nordic WEEE plastics: the current situation}

The literature shows a huge body of statistics and data on WEEE and plastics, both across the Nordic region and more generally across Europe. Invariably, different sources often contain slightly different information from different perspectives, using different definitions and assumptions, and establishing a coherent, reliable picture is rarely straightforward.

Since WEEE plastics are only ever collected as a fraction of WEEE more generally, it is appropriate to begin by examining statistics for WEEE as a whole. The collection of WEEE per se is outside the scope of this project, hence this will not be considered in much detail. It nonetheless provides an essential basis for the following more specific analysis.

\subsection{Overall WEEE collection}

Two main sources - Eurostat (2014) and national WEEE statistics (EEregistret 2014, Naturvårdsverket 2014, DPA-System 2014) were used to establish the total amount of WEEE collected and generated across the Nordic region. For the most part the data from these sources were seen to agree. One major exception concerned the Norwegian WEEE register (EEregistret 2014) which includes three categories of waste in addition to those specified in the EU directive. When these categories are deducted from the Norwegian statistics, the numbers almost exactly agree. The most recent year for which comprehensive data is available is 2010, so this is used in the following analyses. Data from Norway, Sweden and Denmark indicates that the annual amount of WEEE collected was roughly constant between 2010 and 2012 - there was a small fall of several percent over that period. 


\begin{tabular}{lrrrrr}
\hline Table 1: Overall Nordic WEEE statistics, 2010 & & \\
Territory & $\begin{array}{r}\text { Products put on } \\
\text { the market } \\
\text { (tonnes) }\end{array}$ & $\begin{array}{r}\text { Total WEEE } \\
\text { collected } \\
\text { (tonnes) }\end{array}$ & $\begin{array}{r}\text { Total WEEE } \\
\text { collected } \\
\text { (kg, per capita) }\end{array}$ & $\begin{array}{r}\text { WEEE treated } \\
\text { in home } \\
\text { territory or EU } \\
\text { state (\%) }\end{array}$ & $\begin{array}{r}\text { WEEE treated } \\
\text { outside the } \\
\text { EU (\%) }\end{array}$ \\
Sweden & 228,870 & 159,471 & 17.1 & $99.5 \%$ & $0.0 \%$ \\
Norway & 178,483 & 106,834 & 22.0 & $87.6 \%$ & $11.3 \%$ \\
Denmark & 145,959 & 82,237 & 14.9 & $98.6 \%$ & $0.0 \%$ \\
Finland & 145,639 & 50,023 & 9.3 & $99.4 \%$ & $0.2 \%$ \\
Iceland & 7,075 & 1,589 & 5.0 & $97.4 \%$ & $0.0 \%$ \\
\hline
\end{tabular}

Data source: Eurostat.

The table shows the performance of different territories with respect to the EU WEEE directive. It shows that all the territories are currently exceeding the minimum requirements for WEEE collection given in the directive of $4 \mathrm{~kg}$ collected per capita. Norway, Sweden and Denmark are well in excess of the minimum requirement and show by far the highest collection rates in Europe. Whilst Iceland is currently in compliance, its current collection rates are lower than many European territories. The statistics indicate somewhat lower collection rates in Finland, although studies (Toppila 2011) indicate that these do not present a true picture. A substantial fraction - perhaps half - of Finnish WEEE is directed along collection and treatment paths not captured by the statistics. It is expected that the recent Finnish Waste Act will cause the officially recorded WEEE collection rate to rise considerably. The most recent data from the Finnish national register (Ymparisto.fi 2014) relate to 2011, before the Act came into force. Hence there are not yet statistics that formally confirm the true current rate of collection and recycling of WEEE in Finland.

From 2016 onwards the Directive places obligations on territories to collect WEEE according to the amounts of new electronic equipment put on the market. This is initially set at $45 \%$, rising to $65 \%$ by 2019 . Only Sweden (69\%) was compliant in 2010 with the more stringent requirement - all other territories will need an increase from current collection levels by 2019 at the latest.

The amount of equipment put on the market is, of course, only an indirect indicator of the factor of real interest in evaluating the WEEE (plastics) value chain - namely, the amount of electronic waste entering the market each year, i.e. the amount of electronic equipment reaching end-of-life. Understandably enough, this is essentially impossible to measure directly and whilst estimates can be derived based on average usage profiles and lifetimes of different sorts of equipment, such estimates are necessarily approximate. The types of electronic equipment placed on the market (along with their lifetimes) are constantly shifting 
on an annual basis - this has more specific implications for WEEE plastics analysis, as discussed further below.

Eurostat data suggests that only Norway allows significant amounts of WEEE to be treated outside the EU / Nordic region, although this may reflect different reporting / registration practice in different countries. The Norwegian national statistics (EEregistret 2014) give further detail, showing that all of the exported waste is subject to material recycling. Treatment routes for WEEE are considered in further detail in the next section. One should be wary of drawing broad conclusions regarding the treatment of wastes outside as opposed to inside Europe, but it seems reasonable to broadly conclude that the checks and balances afforded by European regulation are desirable.

Based on the above, we can draw the broad following conclusions:

- This project concerns improving the recycling of plastics from WEEE. Improvements in collection of WEEE as a whole are outside the focus of the project, particularly as WEEE is never collected and processed specifically for its plastics content, but would nonetheless prove beneficial.

- Overall collection rates for WEEE are the highest in Europe for the largest territory markets, but there is probably scope for improvement in all territories. Only Sweden is currently in compliance with the most stringent upcoming requirements outlined in the existing Directive. All other territories must improve their overall collection rates, especially Finland and Iceland.

The vast majority of Nordic WEEE is treated in the Nordic region or in Europe, and this should be maintained.

\subsection{WEEE treatment routes}

Before considering specifics relating to plastics in WEEE, it is also necessary to examine the treatment of WEEE as a whole. This is especially important since WEEE plastics treatment is directly and causally related to that of WEEE more generally, since WEEE is never collected nor treated specifically for its plastics content. The opposite is true - as will be discussed further below, plastics are currently regarded strictly as an incidental component of WEEE compared to metals.

Overall treatment rates for WEEE are high in most territory markets. As shown in this Table, over $90 \%$ of WEEE across the region is subjected 
to "recovery" in the common terminology of the EU, defined as material recycling or incineration with energy recovery.

\begin{tabular}{lrrrrr}
\multicolumn{2}{c}{ Table 2: Overall Nordic WEEE statistics, $\mathbf{2 0 1 0}$} & & & \\
Territory & $\begin{array}{r}\text { Total WEEE } \\
\text { collected } \\
\text { (tonnes) }\end{array}$ & $\begin{array}{r}\text { Material } \\
\text { recycling }\end{array}$ & $\begin{array}{r}\text { Incineration } \\
\text { with energy } \\
\text { recovery }\end{array}$ & $\begin{array}{r}\text { Total } \\
\text { recovery }\end{array}$ & Other \\
Sweden & 159,471 & $83.9 \%$ & $7.9 \%$ & $91.8 \%$ & $8.2 \%$ \\
Norway & 106,834 & $81.5 \%$ & $8.4 \%$ & $89.9 \%$ & $10.1 \%$ \\
Denmark & 82,237 & $83.5 \%$ & $7.4 \%$ & $90.9 \%$ & $9.1 \%$ \\
Finland & 50,023 & $88.5 \%$ & $3.1 \%$ & $91.6 \%$ & $8.4 \%$ \\
Iceland & 1,589 & $66.6 \%$ & $14.5 \%$ & $81.1 \%$ & $18.9 \%$ \\
\hline
\end{tabular}

Data source: Eurostat.

The "other" fraction in the Table encompasses a number of elements those fractions of WEEE that are incinerated without energy recovery or landfilled, also accounting anomalies - for instance owing to stock fluctuations caused by material being collected in one calendar year but treated in another.

With the exception of Iceland, all the territories are comfortably in compliance with current EU targets for overall WEEE treatment routes which are specified per WEEE type and are not outlined in detail here, but amount to around $60 \%$ for material recycling and $75 \%$ for recycling and energy recovery combined.

However it should be noted that, particularly with plastics in mind, these should be regarded as first-line statistics outlining the broad initial stage of WEEE handling and treatment. That a particular batch of WEEE is sent to material recycling in no sense guarantees that all of the components in the waste are recycled, merely that "recycling" is the ostensible purpose of the first-line treatment to which the waste is subjected. Much like the effective collection of WEEE as a whole, diversion of WEEE to material recycling is a necessary (but not a sufficient) criterion for the effective recycling of plastics in WEEE.

It is outside the scope of this project to investigate potential improvements at the level of overall WEEE treatment routes. Furthermore, it would seem that for WEEE plastics, the scope for improvement at this level is quite limited. 


\subsection{Plastics in WEEE}

Overall data on the collection and recycling of WEEE is generally more comprehensive than data specific to plastics. Directly available data for Norway and Sweden indicates the overall fraction of plastics in WEEE is around $17 \%$ by mass. A more recent study (Mepex 2013) allows a more detailed analysis, from estimates of the fraction of plastics in the different product groups of the WEEE directive, as shown in Table 3. Earlier similar analyses on a product group-by-group basis (Dimitrakakis et al., 2009 ) indicates a slightly higher overall plastics fraction of around $20 \%$.

\begin{tabular}{lr} 
Table 3: Plastics content by product group & \\
\hline Product group & Fraction of plastics \\
\hline Large household equipment (WEEE Directive Group 1) & $15 \%$ \\
Other household items (Group 2) & $20 \%$ \\
IT and Telecommunications Equipment (Group 3) & $20 \%$ \\
Consumer / lighting / electrical equipment, medical devices (4, 5, 6, 8) & $20 \%$ \\
Toys / leisure / sports, monitoring, dispensers $(7,9,10)$ & $5 \%$ \\
\hline
\end{tabular}

Sources: Mepex.

The Eurostat data for total WEEE collected in Tables 1 and 2 above is also available on a product-group basis. The total amount of WEEE plastics collected is found for individual product groups, and summed over all product groups as:

$\mathrm{P}=\Sigma \mathrm{W}_{\mathrm{i}} \mathrm{f}_{\mathrm{i}}$

Where:

- $\mathrm{P}$ is the total WEEE plastics collected in a given territory.

- $\mathrm{W}_{\mathrm{i}}$ is the total mass of WEEE in product group $\mathrm{i}$.

- $\mathrm{f}_{\mathrm{i}}$ is the fraction of plastics in WEEE in a given product group (taken from Table 3).

It follows that

$\mathrm{W}=\Sigma \mathrm{W}_{\mathrm{i}}$

Where:

- $\mathrm{W}$ is the total WEEE collected in a given territory (the numbers in Tables 1 and 2). 
The average fraction of plastics in collected WEEE for a given territory is $\mathrm{P} / \mathrm{W}$. Table 4 shows the $\mathrm{P}$ and $\mathrm{W}$ values for each territory, hence the total WEEE plastics collected across the Nordic region.

Table 4: Overall Nordic WEEE statistics, 2010

\begin{tabular}{lrrr} 
Territory & $\begin{array}{r}\text { Total WEEE collected, } \\
\text { W (tonnes) }\end{array}$ & $\begin{array}{r}\text { Total WEEE plastics } \\
\text { collected, } \mathbf{P} \text { (tonnes) }\end{array}$ & $\begin{array}{r}\text { Fraction of plastics in } \\
\text { collected WEEE (P/W) }\end{array}$ \\
Sweden & 159,471 & 27,957 & $17.5 \%$ \\
Norway & 106,834 & 18,743 & $17.5 \%$ \\
Denmark & 82,237 & 14,528 & $17.7 \%$ \\
Finland & 50,023 & 8,559 & $17.1 \%$ \\
Iceland & 1,589 & 278 & $17.5 \%$ \\
TOTAL & 400,154 & 70,064 & $17.5 \%$ \\
\hline
\end{tabular}

Data source: Eurostat.

The aim of this part of the analysis was to deduce the mass of WEEE plastics collected each year in the Nordic countries, and it is found to be 70,000 tonnes. The key questions and issues for the rest of the project are as follows:

- To identify the proportion of that mass of plastics that is currently usefully recycled.

- To investigate ways in which that proportion can be increased.

- To examine the challenges and barriers in increasing that proportion.

- To identify ways in which such challenges might be overcome.

\subsection{Treatment of WEEE plastics}

Firstly, it is important to reiterate that although $80 \%+$ of WEEE is deemed to be subject to material recycling, this by no means signifies that $80 \%+$ of the plastics in WEEE are similarly recycled. Both literature sources and consultation with stakeholders make it very clear that the proportion of WEEE plastics recycled is substantially lower than this. Specific data on this issue seems much less prevalent and much more approximate than that for WEEE as a whole - or, indeed, for plastics recycling in product areas other than WEEE.

Mepex (2013) derive rough estimates for Norway of around 3,000 tonnes (about 16\%) but report other studies estimating somewhat higher figures in the $30 \%$ range. A higher figure of around $45 \%$ is posited for Sweden (IVL 2012), but it somehow seems likely that there are significant differences in exactly what is being calculated. Material reported as "recycled" may have been designated in the first instance as sent for recycling, 
but the eventual recycling yield may be considerably lower, even more so for plastics. It seems questionable that the differential in recycling rates between countries is quite as large as these figures would suggest.

Information from Plastics Europe (2013) indicates that the overall recycling rate of plastics waste is around $30 \%$ in Norway, Sweden and Denmark, and around 20\% in Finland, with no data for Iceland. It seems reasonable to assume:

a) that current data for plastics waste as a whole is probably easier to gather and potentially more reliable than for WEEE plastics

b) that plastics in WEEE seem intuitively more difficult to first separate and then recycle than "plastics waste" as a whole.

As such, the $30 \%$ overall figure for plastics waste is assumed to place an upper bound on the estimate for current recycling rates of WEEE plastics. Based on all the above evidence, figures of $10-25 \%$ are taken for the different territory markets, with the lowest rates assumed in Finland and Iceland, and the highest in Sweden. The Mepex study refers to a "gross potential for increased recycling," which is a useful concept here. It is simply defined as the amount of plastics collected (in any given category) that are currently not recycled, and is calculated using the assumed recycling rates and shown in the Table below.

\begin{tabular}{lrrrr} 
Table 5: Estimated gross potential for increased recycling, Nordic WEEE plastics & $\begin{array}{r}\text { Total WEEE } \\
\text { Territory }\end{array}$ \\
$\begin{array}{r}\text { Assumed WEEE } \\
\text { plastics collected } \\
\text { (tonnes) }\end{array}$ & $\begin{array}{r}\text { Estimated WEEE } \\
\text { plastics recycling } \\
\text { rate }\end{array}$ & $\begin{array}{r}\text { Gross potential for } \\
\text { (tonnes) }\end{array}$ & $\begin{array}{r}\text { increased recycling } \\
\text { (tonnes) }\end{array}$ \\
Sweden & 27,957 & $25 \%$ & 6,989 & 20,968 \\
Norway & 18,743 & $15 \%$ & 2,811 & 15,932 \\
Denmark & 14,528 & $15 \%$ & 2,179 & 12,349 \\
Finland & 8,559 & $10 \%$ & 856 & 7,703 \\
Iceland & 278 & $10 \%$ & 28 & 250 \\
TOTAL & 70,065 & & 12,863 & 57,202 \\
\hline
\end{tabular}

It should be reiterated that these figures are estimates that merely attempt to determine the broad scope of the WEEE plastics recycling problem based on the best currently available data. They are probably on the pessimistic side for current recycling rates, as outlined above. Hence the gross potentials for increased recycling are probably overstated.

Furthermore, this gross potential for recycling would clearly not be achievable even under the best recycling conditions conceivable. There are a host of reasons for this (technical difficulties of disassembly and 
separation, separability of plastics, market and regulatory drivers and so on) that will form the basis of the rest of this project.

\subsection{Export of WEEE plastics}

Issues relating to export incorporate a number of distinct elements: intra-Nordic exports from territory to territory within the Nordic region, export from within the Nordic region to elsewhere in Europe, and export from the Nordics to destinations outside Europe.

In addition, there is the necessary distinction between the export of WEEE as a whole and that of particular elements of WEEE (in this case, plastics). The data in Table 1 above shows the proportion exported exEU, but intra-Nordic and intra-EU exports (of WEEE as a whole) are also significant, as shown in Table 6.

As outlined above, a proportion of Norway's WEEE is reported as being exported outside the EU. Norway and Denmark also export substantial amounts of waste within the Nordic / EU region.

Table 6: Export of WEEE, 2010

\begin{tabular}{lr|rr} 
Territory & $\begin{array}{r}\text { WEEE treated in the } \\
\text { home territory (\%) }\end{array}$ & $\begin{array}{r}\text { WEEE exported to } \\
\text { another Nordic / EU } \\
\text { state (\%) }\end{array}$ & $\begin{array}{r}\text { WEEE exported outside } \\
\text { the EU (\%) }\end{array}$ \\
Sweden & $99.9 \%$ & $0.1 \%$ & $0.0 \%$ \\
Norway & $57.6 \%$ & $30.9 \%$ & $11.5 \%$ \\
Denmark & $69.4 \%$ & $30.6 \%$ & $0.0 \%$ \\
Finland & $86.7 \%$ & $13.1 \%$ & $0.2 \%$ \\
Iceland & $1.0 \%$ & $99.0 \%$ & $0.0 \%$ \\
\hline
\end{tabular}

Data source: Eurostat.

The Norwegian national register shows that most of Norway's intra-EU exports are to Sweden, with a small fraction to Germany and traces to other EU territories. The data found for Denmark only specifies the EU, rather than the specific destination territory.

However, even where WEEE is nominally treated in its home territory, it seems clear that substantial amounts of plastics are exported, both within the EU and further afield. For many years, China has been a preferred destination, standing at the centre of a global market in waste plastics. Export rates have recently slowed owing to a change in Chinese policy (the so-called "Green Fence") which restricts the import of lowerquality wastes. Generally speaking, for plastics this means that poorly sorted, unwashed and/or contaminated waste streams may no longer be legally importable to China. Other common ex-European destinations for 
plastics waste such as Malaysia have followed suit in tightening import regulations.

Nonetheless, stakeholders report that legal exports remain significant along with illegal ones, with unsorted mixed plastics still commanding a significant price in the marketplace. Furthermore, there is some evidence to suggest that data should be treated with some caution nominal European treatment may actually involve the first-line sale of waste to European brokers, with the actual waste eventually being shipped overseas.

Based on the available evidence it is not possible to estimate the total amount of WEEE plastics shipped outside the Nordic territories.

\subsection{Losses from collection, sorting and storage of WEEE}

There is extremely limited available evidence on this. Most stakeholders acknowledge that losses occur for a number of reasons including damage during handling or transport, accounting / recording bookmas, theft from facilities and illegal export.

Evidence from Denmark (Danish Ministry of Environment, 2012) outlines two officially noted measures of loss. The first and broadest refers to the difference between the amount of equipment placed on the market and the WEEE collected. As has already been noted, this would only be a highly reliable indicator of loss if equipment placed on the market corresponded directly with equipment reaching end-of-life in any given year. Nonetheless, it is an overall measure of loss that has resonance not least because it is enshrined in the WEEE directive requirements post-2016.

\begin{tabular}{lrrrrr} 
Table 7: WEEE “Iosses", 2010 & & & \\
Territory & $\begin{array}{r}\text { Products put } \\
\text { on the market } \\
\text { (tonnes) }\end{array}$ & $\begin{array}{r}\text { Total WEEE } \\
\text { collected } \\
\text { (tonnes) }\end{array}$ & $\begin{array}{r}\text { WEEE collect- } \\
\text { ed as propor- } \\
\text { tion of put on } \\
\text { market (\%) }\end{array}$ & $\begin{array}{r}\text { WEEE “loss" } \\
\text { (\% of put on } \\
\text { market) }\end{array}$ & $\begin{array}{r}\text { WEEE “Ioss" } \\
\text { (tonnes) }\end{array}$ \\
Sweden & 228,870 & 159,471 & $70 \%$ & $30 \%$ & 95,617 \\
Norway & 178,483 & 106,834 & $60 \%$ & $40 \%$ & 71,649 \\
Denmark & 145,959 & 82,237 & $56 \%$ & $44 \%$ & 63,722 \\
Finland & 145,639 & 50,023 & $34 \%$ & $66 \%$ & 69,399 \\
Iceland & 7,075 & 1,589 & $22 \%$ & $78 \%$ & 5,486 \\
TOTAL & 706,026 & 400,154 & & & 305,873 \\
\hline
\end{tabular}

Data source: Eurostat. 
As noted above, the Finnish figure probably represents a considerable over-statement of loss. This may also be the case for other territories.

A second small source of loss reported in Danish figures (DPASystem, 2014) relates to small accounting differences between WEEE being collected and sent for treatment, although this is a small fraction of the total loss above. A Danish EPA report from 2006 (Planmijø 2006) gives an estimate of illegal WEEE export losses to be around 2,500 tonnes, which was about $4 \%$ of the waste collected or $1.5 \%$ of that put on the market. Both Norwegian and Swedish stakeholders acknowledged the potential for theft from municipal facilities and other collection points, although no statistics were available. No data could be found in the literature either.

Regarding losses during the plastics recycling process itself, little information / detail seems to be available. A study for the Norwegian Environmental Agency (KLIF, 2013) estimated that the potential recycling efficiencies for all thermoplastics - which covers all the plastics of interest here - to be in excess of $90 \%$, although the details are limited.

Taking the overall plastic content in WEEE to be $17.5 \%$ as per the above, this suggests that about $305,873 * 0.175=53,000$ tonnes of WEEE plastics are "lost" through factors that can be attributed to the broader, non-plastics specific, parts of the chain. As we saw in Table 5 above, about 57,000 tonnes of "losses" can be attributed to improvements within the plastics part of the value chain. Hence, whilst this project focuses on the plastics-specific parts, overall the broader value chain remains very significant for the overall recovery of WEEE plastics.

\subsection{Specific types of plastics in WEEE}

The analysis thus far has referred to WEEE as a whole and/or the plastics fraction within WEEE as a whole. In order to better understand the challenges and opportunities in the WEEE plastics value chain, it is necessary to examine which specific types of plastic are most prevalent in WEEE. The specific types of plastic have far-reaching implications, with importance for the technical feasibility of recycling, legal / regulatory requirements, and cost / economic drivers. 


\subsubsection{Overall mix of plastics in collected WEEE}

Many of the previous analyses of the types of plastics in WEEE are quite broad, identifying the major fractions but not looking at the issue in much detail. Most studies highlight acrylonitrile butadiene styrene (ABS), high-impact polystyrene (HIPS), polypropylene (PP), polycarbonate (PC), polyvinyl chloride (PVC), polybutylene terepthalate (PBT) and polyamide (PA). Most reports do not distinguish greatly between WEEE product categories, and the links between product categories and specific plastic fractions are often weak and unclear. A more detailed exposition of the plastics mix in WEEE is desirable for a number of reasons. The plastics mix varies considerably for different WEEE product groups, and this is important for the separability of plastics in a technical and economic perspective.

A fairly comprehensive treatment is presented by Dimitrakakis and co-workers. In a study of waste collected in Germany, estimated compositions of the major plastics fractions for each product group in the WEEE directive (see also Table 12) were identified, as follows:

\begin{tabular}{|c|c|c|c|c|c|c|c|c|c|c|}
\hline & 1 & 2 & 3 & 4 & 5 & 6 & 7 & 8 & 9 & 10 \\
\hline ABS & $40 \%$ & $35 \%$ & $15 \%$ & $42 \%$ & $15 \%$ & $15 \%$ & $42 \%$ & $15 \%$ & $15 \%$ & $15 \%$ \\
\hline PP & $35 \%$ & $35 \%$ & $0 \%$ & $3 \%$ & $15 \%$ & $15 \%$ & $48 \%$ & $15 \%$ & $15 \%$ & $15 \%$ \\
\hline PS & $0 \%$ & $10 \%$ & $40 \%$ & $35 \%$ & $50 \%$ & $50 \%$ & $0 \%$ & $50 \%$ & $50 \%$ & $50 \%$ \\
\hline PC & $15 \%$ & $3 \%$ & $10 \%$ & $0 \%$ & $20 \%$ & $20 \%$ & $0 \%$ & $20 \%$ & $20 \%$ & $20 \%$ \\
\hline PVC & $0 \%$ & $10 \%$ & $0 \%$ & $15 \%$ & $0 \%$ & $0 \%$ & $1 \%$ & $0 \%$ & $0 \%$ & $0 \%$ \\
\hline PBT & $8 \%$ & $3 \%$ & $0 \%$ & $0 \%$ & $0 \%$ & $0 \%$ & $0 \%$ & $0 \%$ & $0 \%$ & $0 \%$ \\
\hline PA & $0 \%$ & $2 \%$ & $0 \%$ & $0 \%$ & $0 \%$ & $0 \%$ & $0 \%$ & $0 \%$ & $0 \%$ & $0 \%$ \\
\hline Other & $2 \%$ & $2 \%$ & $35 \%$ & $5 \%$ & $0 \%$ & $0 \%$ & $9 \%$ & $0 \%$ & $0 \%$ & $0 \%$ \\
\hline
\end{tabular}

Data derived from: Dimitrakakis et al., 2008.

Data on the total WEEE plastics collected (in Tables 4 and 5) is also available on a product group basis. This is combined with the data in Table 8 to give the total amount of each plastic recovered, and its fraction of the total: 


\begin{tabular}{lrr}
$\begin{array}{l}\text { Table 9: Specific plastics in collected WEEE } \\
\text { Plastic type }\end{array}$ & Mass collected (tonnes) & Fraction of total collected (\%) \\
\hline ABS & 23,225 & $33.1 \%$ \\
PP & 12,442 & $17.8 \%$ \\
PS & 15,266 & $21.8 \%$ \\
PC & 6,714 & $9.6 \%$ \\
PVC & 3,186 & $4.5 \%$ \\
PBT & 2,328 & $3.3 \%$ \\
PA & 86 & $0.1 \%$ \\
Other & 6,817 & $9.7 \%$ \\
TOTAL & 70,064 & \\
\hline
\end{tabular}

Data derived from: Tables 5 and 8

This gives a broad upper estimate for the amounts of individual plastics that could theoretically be recycled from WEEE. These figures are useful when considering the potential depth of the end-use markets for recycled plastics. We can see that ABS, PP and PS are the most important plastic fractions, together accounting for well over $70 \%$ of plastics collected. In certain studies, these three plastics account for $90 \%$ or more of the total mix.

In general, ABS/PP/PS plus "other" components is regarded as a mechanically separable and hence recyclable mix. As will be discussed further in the Chapter relating to sorting technologies, separating the styrenic polymers (ABS and PS) from the other polyolefin plastic fractions is seen as relatively routine, the biggest challenge for the recycling technology being the ability to separate the styrenics (Stenvall et al. 2013). The biggest general barrier to the recyclability of all plastic fractions is the potential for hazardous substances, as described in the following section.

\subsubsection{Hazardous substances in WEEE plastics}

Numerous sources (including Wäger et al. 2010, Stenvall et al. 2013) highlight hazardous substances as being the biggest inhibitor of the recyclability of WEEE plastics. The RoHS directive establishes which hazardous substances are in focus for WEEE and plastics - four heavy metals and two types of brominated flame retardants. The presence of these substances above threshold levels effectively precludes the recycling of WEEE plastics, according to the Directive. Technically the Directive only restricts the recycling of plastics back into new EE products (Wäger et al. 2010) but it is widely interpreted as designating plastics containing hazardous materials to be non-recyclable. The aim is that such materials be removed permanently from the value chain, meaning incineration. 
The threshold limits are known as Maximum Concentration Values in the language of the Directive, and are $0.01 \%$ (100 ppm) by weight for cadmium and $0.1 \%$ (1,000 ppm) for mercury, lead, hexavalent chromium, polybrominated biphenyls and polybrominated diphenyl ethers. It is obviously important to understand which - if any - fractions of WEEE plastics are likely to be hazardous and to separate these from other fractions where possible. Wäger et al. (2010) provide the most comprehensive study of RoHS hazardous materials in WEEE plastics. This is based on literature studies and the collated results of many sampling and analysis campaigns across Europe. Norway was the only one of the Nordic territories which played a part in this initiative. The study refers only to plastics originating from waste in Categories 1-4 in the WEEE Directive, although according to our analysis of the Eurostat data, this represents $93 \%$ of the total WEEE plastics collected. The study's findings are many and varied, but are summarised here in terms of the major historical findings, the apparent trajectories of change, and the most recent analyses: 


\begin{tabular}{|c|c|c|c|}
\hline Substance & Historical studies & Apparent trends & Sampling findings \\
\hline Cadmium & $\begin{array}{l}\text { Particularly in TVs and CRT } \\
\text { monitors, many findings well } \\
\text { above MCV from studies in } \\
2000 \text { and as recently as } 2007 .\end{array}$ & $\begin{array}{l}\text { A marked drop in the use } \\
\text { of cadmium and an } \\
\text { effective phasing-out of } \\
\text { cadmium-based additives. }\end{array}$ & $\begin{array}{l}\text { Levels at or near MCV for } \\
\text { plastics in small household } \\
\text { appliances (Group 2), } \\
\text { noticeable for TVs and } \\
\text { monitors but below MCV. }\end{array}$ \\
\hline $\begin{array}{l}\text { Chromium } \\
\text { (VI) }\end{array}$ & $\begin{array}{l}\text { Most findings showed } \mathrm{Cr}(\mathrm{VI}) \\
\text { levels some way below the } \\
\mathrm{MCV} \text {, upper confidence limits } \\
\text { in some studies for TVs and } \\
\text { monitors at or slightly above } \\
\text { MCV. }\end{array}$ & $\begin{array}{l}\text { Ongoing decreases noted, } \\
\text { owing to improvements in } \\
\text { recycling technology as well } \\
\text { as decreasing application. }\end{array}$ & $\begin{array}{l}\text { Detectable levels for all } \\
\text { product groups. Near, } \\
\text { possibly above, MCV } \\
\text { findings for Groups } 2 \text { and } 3 .\end{array}$ \\
\hline Mercury & $\begin{array}{l}\text { All historical findings show } \\
\text { mercury levels below MCV by } \\
\text { several orders of magnitude. }\end{array}$ & - & $\begin{array}{l}\text { Barely detectable levels, } \\
\text { well below MCV for all } \\
\text { product groups. }\end{array}$ \\
\hline Lead & $\begin{array}{l}\text { Some fractions in certain } \\
\text { studies, particularly fine } \\
\text { grained plastics fractions, } \\
\text { found to exceed the MCV. } \\
\text { Concentrations as high as } \\
0.25 \% \text { found in some cir- } \\
\text { cumstances. }\end{array}$ & $\begin{array}{l}\text { Recent studies indicating a } \\
\text { reduction in found con- } \\
\text { centrations, but not as } \\
\text { dramatic as for } \mathrm{Cr}(\mathrm{VI}) \text { and } \\
\text { likely down to technology. }\end{array}$ & $\begin{array}{l}\text { A definite concern for all } \\
\text { product categories. Findings } \\
\text { above MCV levels for } \\
\text { categories } 2 \text { and } 3 \text {, and } \\
\text { close to MCV in other } \\
\text { categories. }\end{array}$ \\
\hline $\begin{array}{l}\text { Brominated } \\
\text { flame retard- } \\
\text { ants (PBDEs, } \\
\text { few if any } \\
\text { PBBs) }\end{array}$ & $\begin{array}{l}\text { Largely absent in household } \\
\text { appliances (Groups } 1 \text { and } 2 \text { ), } \\
\text { present in varying degrees in } \\
\text { other product groups. TV } \\
\text { sets, CRT monitors, tele- } \\
\text { communications equipment } \\
\text { particularly noticeable for } \\
\text { BFR content. }\end{array}$ & $\begin{array}{l}\text { Varies between retard- } \\
\text { ants. Certain older types } \\
\text { (penta- and octa-BDE) } \\
\text { decreasing, but little sign } \\
\text { of immediate decrease in } \\
\text { deca-BDE which was often } \\
\text { used as a substitute for } \\
\text { the older retardants. }\end{array}$ & $\begin{array}{l}\text { Few problems for Groups } 1 \\
\text { and } 2 \text { (household items). } \\
\text { Serious concern - repeated } \\
\text { readings over MCV levels - } \\
\text { for several different BFRs in } \\
\text { Groups } 3 \text { and } 4 \text { (ICT and } \\
\text { telecommunications } \\
\text { equipment). }\end{array}$ \\
\hline
\end{tabular}

Source: derived from Wager et al., 2010.

The following broad conclusions can be drawn regarding WEEE plastics deriving from each of the major product categories (see also Table 12):

- Category 1 (large household appliances): few problems with hazardous materials, with the possible exception of lead.

- Category 2 (small household appliances): lead, cadmium and chromium are possibly problematic, in that order. BFRs are not really a concern.

- Category 3 (IT and telecommunications): all heavy metals are a potential concern, and BFR materials are a serious problem.

- Category 4 (consumer electronics): lead a potential concern, BFRs a definite one. 
The study indicates that it is not always possible to identify particular plastic fractions of concern in particular product groups with any great precision, nonetheless:

- $\mathrm{ABS}$ and PP drawn from Category 1 appliances may contain lead.

- All plastics drawn from Category 2 appliances potentially contain heavy metals.

- All plastics drawn from Category 3 appliances potentially contain heavy metals and BFRs.

- $\mathrm{ABS}$ and possibly PS drawn from Category 4 appliances are problematic for BFRs.

These findings, combined with the calculations above on specific WEEE plastics collected from different WEEE product groups, indicate that around $75 \%$ of all collected WEEE plastics are potentially problematic with respect to hazardous materials. Certain products and product groups, notably TVs and monitors but also other products in the "small domestic" category, appear to give the most problematic plastic fractions.

Stenvall et al. (2013) give a further detailed analysis of WEEE plastics on the market that is highly relevant to this study. They analysed WEEE plastics samples from some of the most significant WEEE plastics recycling sites in Scandinavia, notably the Stena Technoworld facility in Halmstad, Sweden. Perhaps the most interesting finding is that BFR plastics are routinely separated from others by density separation. This is examined further in Chapter 6.3 relating to sorting technologies.

\subsection{End-use markets for recycled WEEE plastics}

Assuming that the difficulties and challenges highlighted above can be overcome, WEEE plastics then, at least in theory, enter the broader recycled plastics market along with plastic waste from other sources such as packaging. In principle, there is a broad range of applications and enduse markets for recycled WEEE plastics.

In the first instance it is perhaps useful to determine the potential impact of recycled WEEE plastics on the market for individual plastics as a whole. Concentrating on the European market, Plastics Europe (2011) provides annual data on market demand. This data for 2010 is combined with the maximum amounts of the major collected plastics from WEEE calculated above, as follows: 


\begin{tabular}{|c|c|c|c|}
\hline Plastic type & $\begin{array}{r}\text { Mass collected in WEEE, } \\
2010 \text { (tonnes) }\end{array}$ & $\begin{array}{r}\text { Total European market } \\
\text { demand, } 2010 \\
\text { (approx., tonnes) }\end{array}$ & $\begin{array}{r}\text { WEEE plastics fraction of } \\
\text { total market }\end{array}$ \\
\hline ABS & 23,225 & 800,000 & $2.9 \%$ \\
\hline PP & 12,442 & $8,000,000$ & $0.2 \%$ \\
\hline PS & 15,266 & $2,100,000$ & $0.7 \%$ \\
\hline PC & 6,714 & 700,000 & $1.0 \%$ \\
\hline PVC & 3,186 & $5,200,000$ & $0.1 \%$ \\
\hline
\end{tabular}

Data source: Table 9 and Plastics Europe, 2011.

These figures show that with the possible exception of ABS, any additionally recovered WEEE plastics could in principle be absorbed into existing markets without undue difficulty. However, the worldwide market status of most these plastics is one of overall oversupply which is not set to change (PCI 2013, ICIS 2011, IHS 2012) and recycled plastics will need to be competitive in terms of quality, functionality, and price.

\subsubsection{Detailed Nordic analysis}

Most reports of recycled plastics markets, and particularly those for plastics from WEEE, are somewhat vague and unspecific. The stakeholder response within this project to date emphasised the importance of market conditions, but did not contain much by way of detail. Our stakeholders reported that establishing and building markets for recycled plastics is extremely important, and that market issues are more important than technological ones in driving improvements.

A more in-depth analysis for several countries - including Denmark, Sweden and Finland in the Nordic region - was performed within the EU-supported Plastic Zero project (Plastic Zero, 2013a). The market demand for recycled plastics was reported as being fairly weak across the Nordic region, mostly because of quality concerns. Recycled plastics were (seen to) not meet the quality standards of domestic manufacturers mostly specialising in "high-quality" plastic products in, for example, the healthcare and food packaging industries. Clarification and quality assurance on recycled material are seen as particularly necessary in these sectors. However, there are considerable differences in emphasis across the region.

Respondents from Denmark painted a fairly pessimistic picture for recycled plastics. Relatively small and fluctuating volumes of recovered plastic are coupled with weak domestic demand and quality concerns. Plastic scrap is sold locally at low prices or shipped, often outside the EU. A vibrant export flow from Denmark to China and Hong Kong reached an 
annual peak of 20,000 tonnes in 2009 but has since declined. The Chinese "Green Fence" may now be the cause of a stockpiling of low-quality mixed plastics inside the Nordic / EU region (Plastic Zero, 2013b)

A broadly similar picture was painted in Finland. Domestic demand for recycled plastics was seen to be weak - and both the Plastics Zero project and the responses in the current project emphasised the need for clear quality standards and certification for recycled plastics, in order to boost consumer confidence in them.

In contrast, most Swedish respondents reported a "robust and growing" market for recycled plastics in which demand outstripped available supply. A rebound in the price of recycled plastics since 2008, combined with a lower cost of recycled plastics compared to virgin material, was reported to drive demand and make recycled plastics competitive in parts of the market. It seems evident that an established intra-EU export operation is an important element of the overall picture.

The differences in response across the region is probably attributable to economies of scale, with larger territory markets proving much more robust and able to recover from downturns. However, even in Sweden the WEEE plastics market appears much more vulnerable than that of recycled plastics more generally - again because of critical volumes and economies of scale. For WEEE plastics, only the largest individual territory markets in the Nordic region (Sweden, perhaps Norway) seem sufficiently large to make the enterprise economically viable. It seems that smaller territory markets will remain dependent on export for the foreseeable future. It is to the Nordic region's overall advantage if economically viable export destinations for WEEE plastics from the smaller markets can be maintained, or established, within the Nordic region rather than beyond.

\subsubsection{Specific applications and markets for recycled plastics}

In principle, the end-use markets for recycled (WEEE) plastics are the same as for virgin materials, for the major plastics listed above as follows:

- ABS is most often found in household and consumer goods, often in the housing of electronic equipment but also many other sorts. Drainpipes and automotive components are two other major uses.

- PP is used for a very wide range of domestic and other applications, such as crates and boxes, containers for food, medical or laboratory materials that require heat resistance, also in construction and automotive uses. 
- High-impact PS is a versatile, impact-resistant plastic that has domestic applications including toys, packaging, electronic housings, and also construction and automotive uses.

- PC can be found in mobile phones, electronic components, construction materials, data storage equipment (e.g. DVDs), automotive and aerospace applications.

- PVC is used extensively for pipework, electrical cable insulation, construction, clothing, furniture and flooring, amongst others.

As ever, perceived quality and price will be the factors that drive the use of recycled plastics in various markets. Fairly clearly, the ideal for recycling of WEEE plastics is making the process as closed-loop as possible i.e. using recycled plastics in the electronic equipment sector. The WRAP organisation in the UK has illustrated specific examples of this, for washing machines at large-scale (WRAP 2013a) and consumer electronics more generally on a feasibility study basis (WRAP 2013b) with promising results.

\subsection{The current situation: summary}

Bringing together the main points from above provides a focus for the ongoing analysis:

- Overall WEEE collection rates are generally high by European and world standards. About 400,000 tonnes of WEEE is collected each year across the region.

- Accounting and reporting developments in Finland will further improve the picture in the statistical sense. Iceland is striving to put in place a more comprehensive system. Overall collection rates can and must rise higher but investigating this will not be a focus in the present project.

- Most WEEE is nominally usefully treated and all territories except Iceland currently meet recycling and recovery targets, although the proportions sent to material recycling could be improved and the proportion exported for treatment could fall.

- The plastics in WEEE collected each year in the Nordic region amounts to around 70,000 tonnes, of which only a small fraction maybe as little as 12,000 tonnes, is currently recycled. 
- An unknown but almost certainly significant mass of WEEE plastics are exported, both inside Europe and further afield, for treatment. Reducing these export flows is a desirable aim.

- Losses of WEEE are highly uncertain, but about $45 \%$ of waste put on the market does not currently find its way into the waste value chain. This corresponds to about 50,000 tonnes of plastics, about the same as the amount of plastics "lost" within the WEEE plastics value chain.

- WEEE contains three main plastic types above all others (ABS, PS and PP) with PC and PVC also present in notable quantities.

- Hazardous substances - heavy metals and brominated flame retardants - are a particular concern, especially in plastics derived from certain types of product (TVs, monitors and domestic telecommunications equipment).

- The end-use markets for WEEE plastics are, in principle, very extensive. In practice, price and quality concerns are potentially serious inhibitors to further recycling. 



\section{Obligations and impact of relevant legal and regulatory frameworks}

\subsection{Overview of key regulations}

The regulatory framework for WEEE plastics has been examined in detail previously (for example Wager et al. 2010) and will only be reprised briefly here. Most, but not all, of the relevant regulations aim to limit and control hazardous substances (in WEEE plastics) to some degree. The key elements under consideration here are:

- The WEEE Directive (The Directive on Waste Electrical and Electronic Equipment), introduced in 2003 and recast in 2012 (European Commission, 2012a). This has already been discussed above in the context of specifying WEEE categories and targets for collection, recovery and recycling targets within these categories.

- The RoHS Directive (The Directive on Restriction of the Use of Certain Hazardous Substances in Electrical and Electronic Equipment), introduced in 2006. (European Commission, 2008a) This specifies maximum levels of certain hazardous substances - certain heavy metals and brominated flame retardants - in WEEE.

- The REACH Regulation (The Regulation concerning the Registration, Evaluation, Authorisation and Restriction of Chemicals), introduced in 2007. (European Commission, 2007) This requires the registration of chemicals in use on the European market if they are supplied in certain quantities, with enhanced reporting requirements (based on exposure and risk assessments) and reduced quantity limits, for substances deemed hazardous or dangerous.

- The Waste Framework Directive, most recently recast in 2008 (European Commission, 2008b). This establishes basic definitions of waste, recycling, recovery and so on. For this project it is most significant in that it enshrines the idea of End-Of-Waste criteria (see below). 


\subsection{RoHS and hazardous substances}

As outlined above, the RoHS Directive restricts the use of four heavy metals (lead, cadmium, mercury and hexavalent chromium) and two types of brominated flame retardants (BFRs) - polybrominated biphenyls (PBBs) and polybrominated diphenyl ethers (PBDEs).

BFRs are widely recognised as perhaps the biggest single challenge with respect to the hazardous nature of WEEE plastics. This is shown in the analysis presented in the previous Chapter, and also emerged strongly in stakeholder inputs to this project. BFRs are strictly controlled on the European and Nordic markets, however most WEEE products are produced in Asia and producers do not face the same regulatory standards or incentives as Nordic actors. Whilst there are changes afoot in the Asian regulatory frameworks (see Bomcheck, 2013) these appear, at best, to be lagging behind European regulation. The evidence discussed above does suggest that the use of the most hazardous materials in WEEE plastics is on the decline. Nonetheless, older equipment remains in use today. Such equipment will continue to reach end-of-life and enter the waste value chain for years to come. The recycling of WEEE plastics containing these chemicals, as is currently reported as widespread for PBDEs under the EU POPs regulation (UNEP, 2010), will contribute to further spread of the chemicals, and may be a source also to human exposure if waste streams are not kept under tight control (Samsonek and Puype, 2013). Moreover, novel chemicals with potential hazardous properties are continuously placed on the market and are gradually replacing known hazardous substances (see EPA, 2014).

Regulations apply equally to imported products as those produced in Europe, nonetheless ex-European producers are clearly removed from the value chain in some sense and hence much harder to influence. Also, national regulations across the Nordic region on BFRs are not fully harmonised. The essence of all regulatory frameworks is that hazardous materials in waste should be removed from the value chain altogether in practice this means that mechanical recycling of hazardous materials is not permitted, that such materials must be effectively separated from other materials in the waste stream, and that permanent removal of such materials in plastics implies incineration (with stringent emissions monitoring and control).

There appear to be differences in national regulations, although confusion and misinformation appears rife. Norway is widely perceived as having stricter national regulations on BFRs than the EU member states, although the Norwegian product regulations (Miljødirektoratet, 2014) 
appear to mirror the requirements of RoHS. There are specific Norwegian regulations with respect to designating wastes containing BFRs above a threshold value of 0.25 percent as hazardous waste, but once again these do not appear to impose additional requirements above and beyond those in existing legislation. The perception may stem from the controversy surrounding the flame retardant deca-BDE, which was initially granted an exemption from RoHS but independently banned by Norway. The RoHS exemption was lifted soon after the Norwegian ban, however, and the regulatory position remains.

Norway is also pursuing further measures against deca BDE in terms of proposing its listing as a Persistent Organic Pollutant under the Stockholm convention. The fundamental control principles of the Convention are to prohibit / severely restrict the production and use of POPs, to restrict their export and import, to make provisions for safe handling and environmentally sound disposal, to restrict / eliminate emissions of unintentionally produced pollutants, and to target additional POP substances as time progresses. This implies a complete restriction on "disposal operations that may lead to recovery, recycling, reclamation, direct reuse or alternative uses..." and also further restriction under the REACH regulation (see below). To align the actions within the European Union with the fact that DecaBDE will be considered under the Stockholm Convention, the European Commission has requested ECHA to start the preparation of an Annex XV restriction dossier on DecaBDE in accordance with the REACH Regulation, and this will be completed in 2014.

Measurement and sampling emerge as major challenges with respect to brominated flame retardants and hazardous substances more generally. In principle, the RoHS Directive is fairly clear and unequivocal - it refers to Maximum Concentration Values (MCVs) in Homogenous Materials (HMs). The latter is defined as "a material that can not be mechanically disjointed into different materials," where "mechanically disjointed" means that "the materials can, in principle, be separated by mechanical actions such as: unscrewing, cutting, crushing, grinding and abrasive processes" (European Commission, 2005). The definition of HM is reasonably clear and sensible for WEEE products, but much more problematic for waste streams.

Stakeholder input to this project repeatedly raised the question of sampling with respect to hazardous substances for waste streams. Plastic waste batches are clearly not homogeneous (in the ordinary sense of the term) with respect to their BFR content and there is a clear concern that large batches of material could be destined for hazardous waste 
handling (meaning incineration) on the basis of unrepresentative samples. The same concern was raised in stakeholder consultation in previous studies, for example that conducted by Mepex (2013). This is an issue that requires further consideration in some detail.

\subsection{REACH}

The Regulation concerning the Registration, Evaluation, Authorisation and Restriction of Chemicals obligates producers or importers of chemical substances in Europe in sufficient quantities (over 1 tonne per year for all substances from 2018) to register such substances with a view to establishing and recording the health and safety implications of these substances, based on a risk assessment approach. It obligates producers to conduct chemical safety experiments, register the identity and labelling of substances, and derive recommendations for safe use. The necessary testing includes costly and complicated animal tests, and it is essentially required, so as to limit animal testing, for multiple producers or users of the same substance to jointly register the substance and share both relevant data and the costs associated with registration. This involves the establishment (or joining) of a Substance Information Exchange Forum (SIEF) which collaboratively establishes a registration dossier for the substance.

There are additional obligations relating to the most dangerous substances, termed Substances of Very High Concern (SVHCs) within the regulation. These include, perhaps most importantly, specific plans to substitute the SVHC with safer alternatives. There are also responsibilities to inform others in the value chain regarding SVHC substances. Regarding hazardous materials typical of WEEE plastics, at present only one brominated flame retardant (hexabromocyclododecane known as HBCDD) is on the SVHC list, although the International Chemical Secretariat produces a longer list of chemicals, based on the REACH criteria (the so-called SIN list - ChemSec, 2013) which could be expected to eventually gain SVHC status. Several of the more common BFRs mentioned above, including deca-BDE, are on this list.

REACH does not specifically apply to waste - in this sense it might be thought of as somewhat incidental to the WEEE plastics value chain. However, it may prove extremely important in a secondary sense. If and when material is recycled, at some point - according to "end-of-waste" criteria which are described in the following section, it loses the characteristic of a waste and becomes a product (or a secondary raw material 
being made into a product). At this point, it falls under the scope of REACH, and this is the source of difficulty.

In order to comply with REACH, a producer clearly has to know the composition of their product in great detail. For processes using primary raw materials, this is relatively straightforward. However, recycled / secondary raw materials arise from recycling processes which have diffuse and unclear input streams. As such, secondary / recycled materials might be considered to be competing unfairly with primary ones. This is noted as a particular problem for plastics, where the inputs to recycling seem especially unclear. The potential for SVHCs represents a particular problem here. The obligation to identify these accurately at the wasteto-secondary material stage means that they must be traced particularly carefully upstream of this.

These considerations make it clear that REACH has implications for actors right along the WEEE plastics value chain. The most important factor for compliance is the collection of reliable, high-quality data and the sharing of this with other actors in the chain. This was specifically mentioned by Danish stakeholders in the interview stage of this project.

\subsection{End-of-Waste criteria}

End of waste (EoW) is a concept enshrined in the EU's Waste Framework Directive, revised in 2008 (European Commission, 2008). The ostensible purpose is to provide an opportunity - "to remove the administrative burdens of waste legislation for safe and high-quality waste materials, thereby facilitating recycling" (JRC, 2013). The European Commission's Joint Research Centre (JRC) has been engaged in the process of developing EoW criteria for various material types in recent years. Once criteria for a specific material type are finalised, formal regulations can be drafted and passed. This has already happened for certain metals and for glass; proposed / draft criteria for plastics are to be released shortly (JRC, 2013). These criteria apply much more broadly than to WEEE, although plastics from WEEE are specifically mentioned. The proposed criteria are extremely complex and cover a range of related issues: product quality (including hazardousness), input materials, treatment processes, the provision of information, and quality assurance.

Members of the project team and stakeholder interviewees have developed interests in EoW criteria to varying degrees. Fundamentally, end of waste criteria establish that, for a waste stream to no longer be specified as waste, four conditions are satisfied - a common use for the 
substance is established, there is a specific market for it, that its use is lawful (that it satisfies technical requirements) and that use will not adversely affect the environment or human health.

The draft criteria for plastics (JRC 2013) establish the following requirements for reaching EoW status:

- Product quality requirements, including limits on non-recyclable plastics, non-plastic components and (in particular) hazardous materials.

- Restrictions on sources of EoW plastics - essentially a total ban on hazardous substances as a source of EoW. A blanket restriction on WEEE was considered but not implemented.

- Broad requirements for treatment, including the strict separation of potential EoW sources from other plastic wastes, and the need for particular care to be paid to WEEE plastics.

- Documentary and quality assurance requirements.

These are obviously interdependent but the first two of these, in particular, establish particularly rigorous challenges for WEEE plastics to qualify as EoW. One stated aim of the criteria is:

"Not make EoW a luxury issue only for the benefit of a marginal part of the total plastic flows, and out of reach for the majority of the plastic flow currently perceived and used by the sector as a product."

(JRC, 2013)

It appears somewhat likely that this aim might be achievable for waste plastics as a whole, but the particular costs and challenges associated with WEEE plastics may indeed mean that EoW is a luxury issue in practice for these waste streams.

Stakeholder input suggests that quality monitoring and assurance may impose particular costs and burdens of responsibility on the recycler, and that these may not be economically attractive to bear, i.e. satisfying EoW criteria might not be worthwhile and leaving the material as waste is better. The restrictions on source / input flow quality could prove particularly problematic in that it is unclear who should be responsible for measuring and assuring this.

Such difficulties can perhaps be overcome if there is a demonstrable economic advantage of waste qualifying for EoW, and if this advantage is shared properly amongst stakeholders, hence providing incentives to 
action for each of them. This implies market / economic drivers for recycled WEEE plastics. Market demand is discussed in more detail in Chapter 7 below. In general, stakeholder input, both from this project and from others (Plastic Zero, 2013a, 2013b) indicates that market demand for recycled plastic is variable across the Nordic region. Recycled plastic is not perceived to meet quality requirements for (limited) domestic manufacture. With regard to WEEE plastics, closed-loop recycling is a remote prospect given the production of WEEE products largely takes place in Asia. Domestic demand seems largely restricted to the larger territory markets (mostly Sweden). In other territories, as has already been mentioned above in other contexts, a small and fluctuating recycled supply chain for recycled plastic often makes the economic viability look very difficult.

Nonetheless, one might argue that EoW criteria do not especially impose additional burdens and responsibilities on the WEEE plastics value chain, above and beyond those discussed elsewhere in this report. Achieving "good practice" in WEEE plastics recycling should enable EoW criteria to be satisfied. 



\section{Specific product focus: Small Domestic Appliances}

Stakeholder discussion, particularly at the first project workshop, led to a decision to focus the project on Small Domestic Appliances (SDAs). This Chapter outlines the particular implications and challenges of the products in focus.

\subsection{Definition in the project}

Project discussions have not focused on a very specific definition of SDAs. A suggested working definition is based on several criteria:

- Data on the amounts of WEEE and plastics collected in different product groups.

- The perceived challenges such as hazardous materials associated with WEEE plastics from different product groups.

- The term SDA itself.

The Eurostat data discussed in Chapter 3 shows that the vast majority of WEEE and associated plastics collected - over 93\% - are derived from waste Categories 1-4 of the WEEE directive. Furthermore, the analysis of hazardous materials in WEEE plastics discussed above also showed Categories 1-4 to be most significant. Categories 6 (electronic tools) and 7 (toys and leisure equipment) were also mentioned in the context of hazardous materials, but the amounts of plastic collected in these categories are relatively small - only $3 \%$ of the total.

We obviously discount Category 1 (Large Household Appliances) and hence take SDAs to represent products in Categories 2, 3 and 4 of the WEEE Directive. This corresponds to $47 \%$ of all WEEE collected, and $54 \%$ of all WEEE plastics.

A non-exhaustive list of specific products is given in Annex II of the Directive, for all categories as follows: 
Table 12: Detailed (non-exhaustive) list of specific products in different WEEE categories

\section{Category Name}

Large Household Appliances Appliances cations Equipment and Photovoltaic Panels

Electrical and Electronic Tools (with the exception of largescale stationary industrial tools

\section{Products}

Large cooling appliances, Refrigerators, Freezers, Other large appliances used for refrigeration, conservation and storage of food, Washing machines, Clothes dryers, Dish washing machines, Cookers, Electric stoves, Electric hot plates, Microwaves, Other large appliances used for cooking and other processing of food, Electric heating appliances. Electric radiators, Other large appliances for heating rooms, beds, seating furniture, Electric fans, Air conditioner appliances, Other fanning, exhaust ventilation and conditioning equipment.

Vacuum cleaners; carpet sweepers; other appliances for cleaning appliances used for sewing, knitting, weaving and other processing for textiles; irons and other appliances for ironing, mangling and other care of clothing; toasters; fryers; grinders, coffee machines and equipment for opening or sealing containers or packages; electric knives; appliances for hair cutting, hair drying, tooth brushing, shaving, massage and other body care appliances; clocks, watches and equipment for the purpose of measuring, indicating or registering time; scales.

Centralised data processing: mainframes, minicomputers, printer units; personal computing: personal computers (CPU, mouse, screen and keyboard included), laptop computers (CPU, mouse, screen and keyboard included), notebook computers, notepad computers, printers, copying equipment, electrical and electronic typewriters, pocket and desk calculators and other products and equipment for the collection, storage, processing, presentation or communication of information by electronic means; user terminals and systems; facsimile machine (fax); telex; telephones: pay telephones; cordless telephones; cellular telephones; answering systems and other products or equipment of transmitting sound, images or other information by telecommunications.

Radio sets; television sets; video cameras; hi-fi recorders; audio amplifiers; musical instruments and other products or equipment for the purpose of recording or reproducing sound or images, including signals or other technologies for the distribution of sound and image than by telecommunications; photovoltaic panels.

Luminaires for fluorescent lamps with the exception of luminaires in households, Straight fluorescent lamps, Compact fluorescent lamps. High intensity discharge lamps, including pressure sodium lamps and metal halide lamps, Low pressure sodium lamps, Other lighting or equipment for the purpose of spreading or controlling light with the exception of filament bulbs.

Drills, Saws, Sewing machines, Equipment for turning, milling, sanding, grinding, sawing, cutting, shearing, drilling, making holes, punching, folding, bending or similar processing of wood, metal and other materials, Tools for riveting, nailing or screwing or removing rivets, nails, screws or similar uses, Tools for welding, soldering or similar use. Equipment for spraying, spreading, dispersing or other treatment of liquid or gaseous substances by other means, Tools for mowing or other gardening activities.

Electric trains or car racing sets, Hand-held video game consoles. Video games, Computers for biking, diving, running, rowing, etc. Sports equipment with electric or electronic components, Coin slot machines. 


\subsection{Challenges presented by SDAs}

SDAs present problems and challenges along the value chain. In the first instance, there are numerous challenges connected with the endconsumer part of the value chain, which are incidental to this project's focus but included here for completeness. These are partly described in the literature (Darby and Obara, 2004) and further developed here:

- Their size means that they are easy to dispose of in general refuse they do not pose any difficulties when considering disposal as, for example, a washing machine might due to its size and weight. Within this project, stakeholder input from Sweden and Finland specifically mentioned the danger of WEEE being disposed of into municipal solid waste. It seems certain this is a tangible risk for all territories.

- Mobile telephones represent a particular challenge with respect to stockpiling. Studies (e.g. Ongondo and Williams, 2011) indicate that $60 \%$ or more of phones are retained at end-of-life by users.

- Many have been produced as "disposable" items that are not intended to be durable, for example, toys with electronic components, and so they have not been manufactured with upgradeability and reuse in mind.

- More products are having electrical and electronic components incorporated into them, which were not present before, for example toys, diaries and novelty items such as badges, pens and cards.

There are also challenges regarding the general recyclability of SDAs i.e. their suitability for recycling at all. With the possible exception of mobile telephones, the size, variety, complexity and cost of small products to- 
gether with low market demand often makes repair, refurbishment, reselling and recycling less viable than with larger items.

Perhaps most directly relevant for this project are the specific technical challenges relating to recycling and recovery of plastics from SDAs. This product group was chosen partly because it presents particular challenges, certainly when compared to other groups such as large white goods, which have relatively well-established recycling regimes and materials that present fewer problems.

The project workshop explored some of these:

- SDAs are increasingly technical and complicated, meaning they are difficult to disassemble.

- They have a complex mix of plastics, metal and other components for which well-established recycling systems are still being developed.

- In pure economic terms - which are ultimately likely to drive recycling of the product group as a whole - plastics are especially unimportant compared to high-value metal components.

- They are a product group for which the plastic fraction is likely to be relatively rich in hazardous materials (BFRs to some degree, also heavy metals). They are also a highly variable and heterogeneous group in terms of composition. This has implications for the suitability of treatment regimes.

The data discussed in Chapter 3 above, on plastics content and WEEE collection in different product groups, can be used to highlight the overall scope of the WEEE plastics issue in SDAs. Based on the 2010 Eurostat data and the composition data in Table 8 , it emerges that:

- SDAs constitute about 188,000 tonnes (47\%) of the Nordic WEEE collected in 2010

- About 38,000 tonnes are SDA plastics, this is about 54\% of all WEEE plastics

- $\mathrm{ABS}(11,500$ tonnes) and PS (12,900 tonnes) are the main plastics collected from these products.

In summary, the potential for increased recycling of plastics from SDAs across the Nordic region is at least 20,000 tonnes per annum. Achieving anything like this potential will require attention across the value chain, on the technical, regulatory, economic and market level. 


\section{Routines, standards and technologies for sorting within Europe and the Nordic countries}

This Chapter focuses mostly on the technological challenges connected with WEEE plastics recycling. In addition to the market and regulatory factors discussed in the above Chapters, and the drivers described later, the effective recycling of WEEE plastics also depends strongly on the specific sorting and processing regimes.

\subsection{General scope of the issues}

For waste plastics recycling in general, a common call from stakeholders is for initial sorting as close to source as possible (see, for example Plastics Zero, 2013a). There is a clear distinction between regimes and/or technologies for pre-treatment (e.g. collection, pre-sorting) and reprocessing (e.g. production of recyclates or granulates). The latter is mostly a technological issue whereas the former is mostly concerned with manual handling of one form or another.

For WEEE plastics, initial collection and source-sorting is obviously constrained by broader issues to do with WEEE as a whole. Regarding the focus of this project on SDAs, in the first instance large and small WEEE items are source-separated quite effectively. They go along quite different treatment paths right from the point of the consumer. For the purposes of our analysis here, we can assume that we have a mixture of small WEEE items, from which we ultimately seek streams of highquality secondary plastics. To achieve this there are three elements of the sorting and processing regime that need consideration: 
- Reliable and accurate separation of plastics fractions from other WEEE elements, principally metals.

- Reliable and accurate separation of WEEE plastics into hazardous and non-hazardous fractions, essentially BFR-rich vs. BFR-free fractions.

- Reliable and accurate separation of the non-hazardous WEEE plastics mix into individual plastic fractions, ideally with a high degree of purity.

An earlier study by DEFRA in the United Kingdom (DEFRA 2007) illustrates the overall processing scheme.

\section{Figure 1: Overall flowsheet for WEEE Processing}

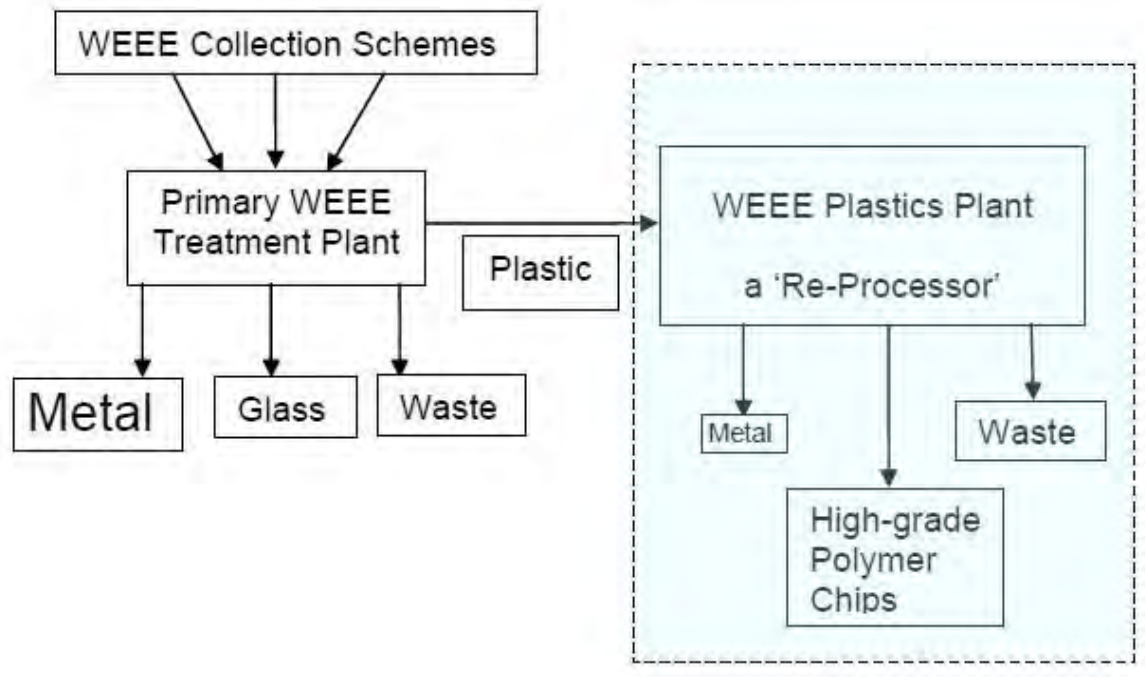

Source: DEFRA, 2007.

For the purposes of this project, we are effectively ignoring the first of the steps listed above and concentrating on the "WEEE Plastics ReProcessing" activities as illustrated in Figure 1. The upstream "Primary WEEE Treatment" activities are the general responsibility of the general WEEE treatment value chain; whilst they may concern the same actors as the plastics elements, they are taken as separate here.

Furthermore, the focus is mostly on mechanical recycling of plastics. This refers to physical means of processing where chemical structures of the material remain unchanged. The EU's technical proposals for end-ofwaste criteria (JRC, 2013) contain a detailed exposition of the recycling processes, listing the main basic operations as: cutting, shredding, sort- 
ing, removal of contaminants, floating / cleaning, extrusion, filtering and pelletizing. Together these processes generate saleable secondary plastics products. Chemical recycling, which involves a chemical transformation of the feedstock, presently accounts for a very small proportion of recycling activity (JRC, 2013) and will not be considered further here.

\subsection{Pre-processing of WEEE plastics streams}

The second and third stages of separation listed above - separating hazardous materials and individual plastic fractions - are not completely separate and independent as the list might suggest. The mixed plastics stream from mainstream WEEE treatment needs further processing before the separation of plastics fractions, involving some or all of the following steps outlined in the DEFRA and EU studies mentioned above (DEFRA 2007, JRC 2013):

- First-stage size reduction, down to perhaps $20 \mathrm{~mm}$ particle size.

- Removal / extraction of contaminants (metals, fines and dust, wood, rubber, stone, glass).

- Further size reduction to perhaps $5 \mathrm{~mm}$ particle size.

There are a wide selection of proven available technologies for these steps (DEFRA 2007, WRAP 2011) including shredders, impact and ball mills, granulators, gravity, electrostatic induction or eddy current separators for metals reduction, and gravity or centrifugal separators for removal of wood / rubber / glass. It is widely accepted that such techniques can be deployed by WEEE processors without difficulty (JRC 2013).

\subsection{Separating plastics}

The more interesting and challenging steps concern the separation of plastics fractions from each other. In this project, stakeholders directly involved in WEEE plastics processing were reluctant to give specific information about separation technologies. However, the current stateof-the-art and the challenges faced can be determined to some degree from material in the public domain. A number of actors in the European area are concerned with the development (Axion Consulting, 2013) and 
deployment (MBA Polymers, 2013) of commercial-scale technologies for the separation and recycling of (WEEE) plastics.

The issues for WEEE plastics can be summarised as follows. After shredding and pre-processing to remove metals and other contaminants, WEEE plastics streams will contain a mixture ABS, PS and PP with small amounts of other plastics and considerable amounts of BFRs. The aim is to produce as pure streams of the individual plastics as possible. Contamination of some plastics with others may affect saleability and value, but otherwise does not represent a very serious problem. On the other hand, contamination of plastics streams with BFRs above threshold limits is completely unacceptable.

Density (sink-float) technologies are widely reported as being viable for some of the necessary separations. A US patent (Schlummer and Maurer, 2012) details sink-float capability for separating BFRs from other plastics, and also different plastics from each other. Sink-float is reported as being in use to separate BFR plastics (Stena, 2014) The EU study (JRC, 2013) describes float and sink technologies for plastics separation as "conventional", and there are numerous examples on the market. Sicon Technology (2014) is one example of a commercial supplier of this form of technology.

The polyolefin fractions (PP in this case) are trivially separated from other elements simply using water as a separation medium, since the density of PP is markedly lower than $1 \mathrm{~g} / \mathrm{cm}^{3}$ and hence it floats readily in water. This also allows polyethylene to be separated when present, although this is more important for e.g. packaging waste than WEEE. This separation is reported (see for example, EPIC 2006, Navarini 2014) as being almost perfectly effective. Recovery rates of the floating polyolefin fraction exceed $98 \%$ and purity approaches $100 \%$. Separation of BFR fractions is also, in principle, straightforward. They have densities in excess of $2 \mathrm{~g} / \mathrm{cm}^{3}$ and are typically present in such quantities that the separation of a very clean plastics fraction is readily achievable. The density of the styrenics (ABS and PS) is around $1.1 \mathrm{~g} / \mathrm{cm}^{3}$ and a miscible solvent - glycerine or salt solution - must be mixed with water to create a suitable flotation solution. Sicon Technology (2014) reports purities in excess of $99 \%$ with modular solutions affording throughputs of several tonnes/hour.

The WRAP organisation in the UK built upon the earlier DEFRA (2007) study to highlight and investigate the feasibility of a number of potential WEEE plastics sorting technologies (WRAP 2011), including near-infrared (NIR) technology developed by Titech (Tomra Group). The Nordic Waste Group Plastic Waste Project (Norden, 2014) reports NIR 
being used routinely in the recycling of household plastic waste, by operators such as Swerec AB in Sweden. The WRAP study found that NIR is suited to separating somewhat larger particles typical of plastic packaging wastes $(10 \mathrm{~mm}$ or larger) but much less suitable on particle sizes typical of WEEE plastics (around $5 \mathrm{~mm}$ ). Smaller particles have implications for the resolution of the detectors and the necessary speed of conveyor belts to achieve viable throughputs. In addition, NIR is found to be unable to detect black-coloured plastic; this is already recognised as a problem in the packaging waste arena. The study concluded that the Titech NIR technology is technically and economically feasible for the separation of WEEE plastics, although there are complicating factors.

The evidence suggests that technology to produce an essentially clean PP stream and an essentially BFR-free mixture of the heavier plastics can be acquired almost off-the-shelf. However, the most difficult of the separations - ABS from PS - is widely recognised as being important for the saleability and value of the recyclates, and hence for the economics of the whole enterprise. Specific information on this step of the separation is somewhat more scarce at present than for the earlier steps. However, European actors such as Hamos Separation Technologies report that electrostatic separation processes can be used to separate ABS and PS, producing streams with purity in excess of 98.5\% (Köhnlechner 2013). Processing lines for PS and ABS separation are capable of running with a throughput of $1,500 \mathrm{~kg} / \mathrm{h}$.

It is evident that effective separation of WEEE plastics in this fashion involves at least two and possibly three separate steps - separation of PP, removal of BFRs and separation of the styrenics. In practice there will be other plastics fractions in the overall mix, at small but more than trace concentrations. Further handling of the float and sink fractions at each stage is obviously necessary, along with the regeneration / recycling of float medium and downstream drying. This implies fairly complex process plant, which in turn requires considerable investment. It is therefore reasonable to conclude that this presents something of a barrier to new players in the WEEE plastics separation market, and that the apparent concentration of commercial-scale working expertise in WEEE plastics recycling is unsurprising. Nonetheless, there appear to be few significant technological barriers to the separation of WEEE mixed plastics. 



\section{The WEEE plastics market}

This Chapter builds on the overall picture painted in Chapter 3, in the context of the regulatory frameworks and in light of the sorting technologies in the intervening Chapters. It further investigates the structural, regulatory and market forces that drive the collection and management of WEEE and plastics across the Nordic region. The findings are based on literature, the stakeholder interviews by the project team, and inputs from stakeholders at the first project workshop held in November 2013 in Oslo.

\subsection{Collection and Recycling of WEEE: EPR systems}

The initial collection and recycling of WEEE is driven almost exclusively by the notion of Extended Producer Responsibility (EPR). This has been developed over the past two decades as a means of the management and improvement of products in an environmental perspective. It applies to a number of product groups and shifts the responsibility for end-of-life treatment onto those responsible for placing the products in the market. In principle this is intended to encourage better design in the environmental perspective in the first place.

EPR schemes for WEEE are in place in all Nordic territories. The legal, regulatory and practical details vary between territories - with some considerable differences - although the overall essence is broadly similar in each. WEEE is collected from the domestic end-user via a combination of municipally-operated and private routes: municipal waste centres, retailer take-back, and some kerbside collections. Transport, handling and processing of WEEE is generally undertaken by private actors, which are funded and supervised by one or more recycling companies, which may themselves be in competition, that are answerable to national governments. The recycling companies are generally membership organisations, and are funded by subscriptions from technology producers and importers. These costs may in turn be passed on to the consumer through a specific price element.

The largest territory markets exhibit quite marked differences in their EPR structure, despite the overall objectives being essentially identical. 
The main differences are at the level of actor that interfaces directly with the national government through its environmental protection agency:

- In Sweden, the focus is very much on producer collective organisations. There are two of these, one of which (El-Kretsen) seems dominant - it represents most of the producers and works alongside the municipalities to channel virtually all officially collected WEEE through a single route. El-Kretsen engages a range of transport and treatment contractors for the later stages of the value chain.

- In Norway, the market at this level is represented by five companies (effectively four given mergers) which are in competition. This is not a free market - companies must be approved by the authorities and have responsibilities for waste introduced to the market by their members - but is nonetheless quite different from the Swedish system. Producers may adopt individual responsibility, but there are none of these currently registered in Norway.

- In Denmark the market similarly contains a number of producer collective organisations in competition, although one of these (Elretur) is fairly dominant. In addition there are a large number of individual producers on the WEEE register, although the collectives account for the majority of the market.

- The Finnish system seems quite similar to that in Denmark - there are a number of producer organisations but producers can also take individual responsibility. Åland has a similar structure, and the producer responsibility organisations of Finland are active there. All waste is shipped to Finland in the first instance.

Stakeholders report strengths and weaknesses in each of these systems. The Swedish system, as well as being quite centralised in structure, appears very closely managed - for instance regarding the monitoring and control of waste flows right along the value chain. This evidently contributes to the high overall collection rates for WEEE reported in the previous Chapter. The system ensures quality and transparency. However, some consider El-Kretsen to have too much power in the market. This may mean that wastes are under-valued and actors, particularly municipalities, may seek to sell to agents other than El-Kretsen. This may raise the temptation for waste-holders to circumvent official channels, particularly with plastics from WEEE.

The Norwegian system is seen as a relatively competitive marketplace (Hjellnes Consult, 2008). It is also seen as being quite unstable 
with respect to demand, collection, waste composition, contracts and competition. The division of the market is seen to dilute the focus on recycling, with a lack of emphasis on recycling in favour of a focus on price and volume, in an effort to secure market share. Some stakeholders emphasise the value of competition to create a healthy market, but possibly at the Norwegian national level this makes the market too diffuse in certain respects. The wide and shifting range of different electronic products makes it impossible for many actors in the value chain to have knowledge about all of them. This may be the root of the "lack of ambition" in the WEEE plastics field that is noted in more recent Norwegian analysis (Mepex, 2013). Division of the market via this EPR system also increases the risk of freeloading (Hjellnes Consult, 2008). Small material volumes in geographically remote areas - which are costly to collect, transport and process - are especially vulnerable for official treatment channels to be circumvented.

Danish stakeholders report many similar opinions to their Norwegian counterparts. The public-facing aspects of the EPR system seem positive - there is a good culture of recycling and the public recycling stations work well. A focus on cost (but especially price) is noted as in Norway - this is not necessarily conducive to recycling over other treatment options. It was suggested that making confidential price information public might enhance the system in absolute objective terms, but would not be in the interests of the major actors currently in it. The collective schemes are seen to concentrate market power with relatively few actors, as in Sweden, but the typically short-term and fluctuating nature of the market - particularly with recyclers - is not conducive to forward planning, investment and development towards better practice and novel solutions.

As mentioned above, reported collection rates in Finland are considerably lower than in the other major Nordic territories, although it would seem that reporting workflows rather than structural systemic issues lie at the heart of this. Recent legislation has prohibited activities that were previously legal but outside the official system - including waste management companies, scrap dealers and other actors who would collect WEEE from consumers. The tightening of the legislation should result in improvements both in practice and in record-keeping, although there may be some cultural issues to overcome. These issues seem to refer to WEEE as a whole rather than plastics specifically.

Iceland has established effective EPR systems for other product groups (notably for fishing-related equipment) but not yet for WEEE (Norden, 2013). Current systems have more of an appearance of indi- 
vidual producer responsibility schemes, but legislative plans in place (Ministry for the Environment and Natural Resources, 2013) indicate that the establishment of what appears more like a Nordic EPR scheme will follow shortly.

In summary, whilst there is some scope in improving the recycling of WEEE (and hence plastics) through systemic changes to extended producer responsibility schemes, in overall terms these appear somewhat indirect. Changes in Finland (and in relative terms in Iceland) may have more of a direct effect. However, potential systemic changes have consequential effects - possibly more specific to plastics-related issues which will be examined further below.

\subsection{WEEE Plastics: Knowledge, Information and Competence}

This section highlights the results of stakeholder interviews across the region, also input from the project workshop, concerning the state of current sector knowledge about plastic in WEEE and its recycling. Immediate and obvious conclusions from this analysis include that much that is known by experts and researchers, both on plastics and on recycling technology and practice, is not known by practitioners in the sector. Also, information that could conceivably be gathered and used to improve practice is often simply not collected, usually for economic reasons.

Stakeholders in all territories report that key actors' knowledge of the plastic content of WEEE products is often fairly weak. That there are wide, and constantly shifting, ranges both of WEEE products themselves and plastic content therein, emerges time and time again in stakeholder discussions as a serious barrier to progress.

Often the "producer" in the Nordic value chain is actually an importer - the actual manufacture takes place outside Europe. Whilst this does not dilute the importer's responsibilities, in practice it means that potentially useful information is a further step removed from the value chain in question. Nonetheless the major Asian manufacturing territories including China, Korea and Malaysia have their own versions of key regulations such as RoHS in place. Whilst the details vary somewhat the broad scope is similar to that in Europe. Such regulations do not generally apply to exports - the responsibility lies with the importer. Nonetheless manufacturers also serving domestic / Asian markets can be expected to be broadly aware of requirements and amenable to discus- 
sions with European actors - for instance with respect to improved design for recycling and eliminating hazardous materials.

Some interesting contrasts in the information flow are observed in different Nordic territories. Danish stakeholders indicate that businessto-business waste plastic flows may be relatively well characterised where actors share information about it, whereas post-consumer waste collected at public recycling stations is relatively poorly characterised. In contrast, in Sweden many business-to-business flows are outside the official management and reporting chain, and hence information on these is unregistered and relatively less well known. Public recycling station waste is relatively closely managed in Sweden, however kerbside collection is not (IVL, 2012).

With regard to the technological and practical aspects of WEEE plastics and recycling, it appears that knowledge, expertise and experience is largely concentrated with a limited number of actors. The principal reasons for this - the need for relatively complex processing, substantial investment and hence large, relatively steady and predictable waste flows were outlined above. The Stena group - and in particular their Halmstad facility in Sweden, appear to be a particularly clear example of this.

However, it seems clear that substantial amounts of WEEE along recycling routes where the actors' primary focus is metal recycling over and above plastics recovery. As we have seen in Chapters 3 and 4 above, effective recycling of WEEE plastics may not bring particular advantages:

- In terms of official statistics and targets, first-line treatment of WEEE as a whole is what matters - and that WEEE can be deemed "material recycled" with no account taken of the fate of its plastics.

- Regulatory drivers are much more about eliminating bad (hazardous) materials / plastics from the value chain than the recovery of good ones; also, quantity has primacy over quality.

What this means is that there must be a clear economic imperative for recycling actors to engage with plastics as well as metals.

\subsection{WEEE Plastics: Market Conditions}

This section builds on the above and on Chapter 3.8 referring to end-use markets for WEEE plastics. It highlights and reinforces the major market-related factors that present barriers to and opportunities for WEEE plastics recycling. 


\subsubsection{Producer interest in WEEE plastics recycling}

Market interest from the perspective of the recyclers was addressed in the previous section. However it also needs to be considered in a different perspective - that of the EPR organisations, the producers and their collective bodies.

At the EPR level, the funding flows for waste treatment and management appear to be essentially quantitative - entirely dependent on mass / volume of waste treated. This stems from the fact that the basic regulatory obligations and targets enshrined in the Directives that establish EPR schemes are quantitative - producers take responsibility for the waste associated with their own products, but quality of handling is only enshrined in minimum / threshold standards. Beyond meeting these standards there is little or no incentive for value chain actors to pursue quality. As such, one could argue that at least some of the ostensible purposes of EPR schemes, as applied to WEEE and specifically plastics, are weakly reflected. As expressed by the originator of the EPR concept:

"The establishment of this feedback loop from the downstream (end-of-life management) to the upstream (design of products) is the core of the EPR principle that distinguishes EPR from a mere take-back system..."

(Greenpeace, 2006)

It is a considerable stretch to suppose that this feedback loop is established meaningfully for WEEE plastics. There may be some scope within the structure of producer responsibility schemes and their application to improve matters, and this is in the sphere of influence of Nordic national governments. This point will be further discussed below.

\subsubsection{Market division}

A recurring theme in literature sources and stakeholder consultations is the bearing that market division has on the recycling of WEEE as a whole, of plastics as a whole, and of WEEE plastics in particular. As mentioned for incentives above, the market can be more or less thinly divided at the level of EPR companies, of waste transporters and of waste treatment agents. As has already been noted, at the EPR level there are marked differences across the Nordic territories (relatively centralised in Sweden, less so in Finland and Denmark, and relatively competitive in Norway). At the level of transporters and treatment agents, the market is fairly disperse in all territories. El-Kretsen engages dozens of 
transport companies and waste treatment agents (El-Kretsen, 2011) and this is replicated elsewhere in the Nordics.

Stakeholders report that competition and division of the market (at whatever level) is probably effective at driving down costs, but may have implications for quality - indeed, that cost and quality are often seen to be at direct odds with one another.

An illustrative example concerns predictability and stability within the market. Stakeholders report that these features are largely absent, partly for reasons that have been outlined above - that waste streams exhibit constant shifts in volume and composition. However, market stability is also strongly influenced by the relationship between EPR companies and contractors. This is typified by short-term contracts for transport and treatment (12-24 months at a time is typical). El-Kretsen and other EPR organisations have referred specifically to the need to maintain pressure on sub-contractors, principally in an ongoing effort to control and lower costs. However, this is reported by stakeholders to be a very important disincentive for investment and innovation. The result is that a very small number of "big players" have invested and innovated, whereas most have not. Whilst it may be desirable in principle to focus the market on those big players, this is not necessarily efficient or desirable in practice (for example, this might obligate the transporting waste $2000+\mathrm{km}$ for pre-treatment). There is also a danger of complacency, a lack of urgency and ultimately upward pressure on costs / prices if the market becomes too coarse-grained.

However, there is some evidence to suggest that over-dividing the market through competition might be compromising economic viability as well as quality. Perhaps unsurprisingly, this is reported most strongly in Norway. A relatively competitive market at EPR company level, combined with a scattered population and hence small, geographically dispersed volumes of waste, presents a number of risks for inefficient operations. Duplication of effort - for example multiple contractors undertaking collections of small waste volumes in the same remote areas - is a distinct risk. Inefficiency is a similar risk in urban areas with relatively high volumes of waste. Freeloading (failing to take responsibility) is seen as a particular risk in thinly divided markets, especially as elements of the market undoubtedly run at a marginal loss - the waste effectively has negative value. 


\subsubsection{Potential for market development: opportunities and challenges}

Given little or no systemic change, the potential for expansion of the Nordic WEEE plastics market is considerable. The analysis in Chapter 3 above shows that, from the supply side, the market is currently rather small (10,000-20,000 tonnes per annum) and could expand considerably with no systemic market change. An additional 110,000 tonnes of supply is theoretically possible as outlined in Chapter 3.6, about half (53,000 tonnes) arising from enhanced collection of WEEE in general and a similar amount (57,000 tonnes) from improvements in current plastics recycling practice. As shown above, in principle even this wildly optimistic additional level of supply could be tolerated in world markets that are tens if not hundreds of millions of tons per annum deep across the range of plastics as a whole.

More generally, the potential for market development depends on two factors, which are broadly carrot-and-stick, respectively:

- The attractiveness, quality and price of recycled WEEE plastics in the global plastics marketplace in competition with virgin materials and plastics from other sources - including other recycling value chains.

- The attractiveness of recycling WEEE plastics in "competition" with other waste management strategies (landfill, incineration and so on) in the context of relevant policies, regulations and directions.

Whilst in principle the market for recycled plastics is deep, the practical reality is different. Nordic stakeholders, both in this project and others, are reporting weak demand. From the project workshop:

\footnotetext{
"The demand for recycled plastics is not matching the supply of recycled plastics. This is particularly so for Europe. After China's "green fence" prices have dropped as demand in China has dropped. The few market options make incineration a tempting option. Furthermore, the lack of shared operational standards and quality ratings in the business itself is also causing difficulties as the market finds it difficult to know what to ask for."
}

(Nordic Workshop 2013 - Annex B)

With respect to operational standards and quality regarding recycled plastics, the EU technical proposals on End-of-Waste criteria contain a huge amount of information which should be examined and interrogated by relevant stakeholders. With particular respect to WEEE plastics, the 
market could be protected to some degree by encouraging more closedloop recycling practice. As mentioned above, specific examples of this in the United Kingdom have been proven to work on a limited scale. Washing machine parts manufactured from $100 \%$ recycled plastics originating from refrigerators have been deployed commercially (WRAP 2013a) and the feasibility for using recycled plastics in high-end audio equipment has been demonstrated (WRAP 2013b). It is imperative to open dialogue with manufacturers to investigate further possibilities in the Nordic region. This and other suggestions were mentioned in the project workshop:

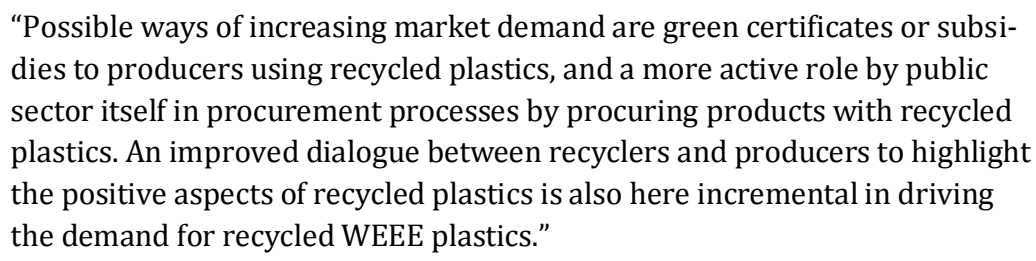

(Nordic Workshop 2013 - Annex B)

The area of "green certification" could include demonstrations to manufacturers how the enhanced use of recycled plastics could improve the environmental performance of their products, including Environmental Product Declarations (EPDs).

There are no indications that ongoing regulatory changes will have a significant impact on product quality requirements for recycled WEEE plastics. Perhaps the biggest potential change is the possible listing of the flame retardant deca-BDE as a Persistent Organic Pollutant (POP) under the auspices of the Stockholm Convention. Were that to occur and a decision is several years hence - there could be an effect, although this would depend on the precise nature of any listing and the picture is far from clear. Analysis from New Zealand (Ministry for the Environment, 2013) suggests "major consequences" for the WEEE recycling industry, up to and including necessitating the landfill of deca-BDE plastic waste, although the details remain unclear. 



\section{Success criteria, opportunities and barriers}

This Chapter synthesises the information in the previous Chapters, in an attempt to bring together the major opportunities, barriers and risks for developing WEEE plastics recycling in the Nordic region. These include elements that might be further investigated within the project, and those that may eventually form recommendations from the project.

\subsection{Opportunities and barriers}

The following factors are kept in mind when considering potential opportunities and barriers to progress:

- Realistic opportunities should be focused upon elements that the Nordic Waste Group, and more generally the governmental / NGO sectors, can reasonably influence. For example, direct intervention in relatively free private-sector markets is not a realistic aim. Indirect influence, perhaps via regulatory drivers or incentives, is more realistic.

- Evolution not revolution: in many respects Nordic practice in WEEE, plastics and recycling is already world-leading. Revolution may not be desirable even if it were achievable.

The following areas would seem to merit particular attention.

a) Better understanding the scale of the problem.

The value chains for WEEE plastics are complex. In the short-term, a workable goal might be to better document how much plastic is actually recycled - as seen above, the data on this seems scant and uncertain at present. In a longer term perspective, it may be possible to establish specific goals for the material recycling of WEEE plastics, and particularly those from SDAs. These goals could concern quantity and eventually quality issues. Eventually, differentiating between plastics and setting targets and goals specific to particular plastics could be valuable. 
b) Develop and share better understanding of the value chain.

The input flows to WEEE plastics recycling remain diffuse and tracing material through the value chain is poorly understood. Guidelines for this - possibly as an outcome from pilot projects - could be developed and shared.

c) Develop interest in the WEEE industry about plastic recycling.

The value of plastic waste as a recyclable is under-appreciated by at least some WEEE recyclers. The project guide resulting from Part 2 should emphasise and promote this, encouraging more WEEE recyclers to enter the plastic waste value chain. However the "easy" markets of the past, particularly the Asian export markets, are now drying-up in terms of volume and price. The barriers to entry for new players in WEEE plastics recycling, in terms of investment and securing a stable, viable supply, are considerable. Nonetheless, there is a huge untapped supply which should be investigated. Some of the necessary information and expertise is in the public domain. A possible avenue for the present and similar projects might concern how to synthesise and communicate such publicly available information.

d) Improve market / consumer perception of recycled plastics

Recycled plastics appear to have a place in the Nordic market, but mostly as a low-to-medium quality product. There may be some potential in drawing distinctions between WEEE plastics and those from other sources such as packaging. It may be possible to engender a greater sense of quality in WEEE plastics. International actors with a strong European presence, for example MBA Polymers in Austria, strive to market recycled plastics as the equal of virgin material in many respects. The potential for elements of near closed-loop recycling in the electronics sector, as illustrated in the WRAP work in the United Kingdom (WRAP 2013a, 2013b), should be further investigated. Project outputs, highlighting such examples, should be directed at manufacturers.

e) Reduce the shipping of WEEE plastics

The Chinese "Green Fence" and similar measures in other Asian destinations forces Nordic and European actors to be more creative and innovative in their dealing with plastics waste - roughly-mixed, poor quality 
waste no longer commands a decent price on the legitimate market. However, intra-Nordic and in particular intra-EU plastic waste shipments now constitute a missed opportunity and a loss of value in this area. In order to improve matters, the Nordic region should:

- establish the current capacity across the Nordic region for bestpractice treatment of WEEE plastics. It seems clear that this capacity is currently not fully utilised, but that the potential supply of waste plastics - from WEEE and other sources - would overwhelm current capacity

- devise measures to ensure that Nordic wastes are channelled along these best-practice treatment routes

- examine ways of establishing state-of-the-art treatment capability more widely across the Nordic region.

f) Consolidate and stabilise markets.

It seems clear that markets at different parts of the value chain are too diffuse and could benefit from consolidation and enhanced stability. This concerns national governments and their environmental protection agencies, the actors directly interfacing with governments (EPR organisations) and actors directly engaged in recycling. Instability and shorttermism in these markets is the enemy of quality. Over-consolidation does however carry risks, and these should be carefully considered. There is also the question of the degree to which "free" markets can realistically be manipulated. Norway has provided a recent example of the type of discussion and analysis that might be relevant here (Konkurransetilsynet 2013), where the competition authorities illustrated the perhaps unexpected and perverse - anti-competitive risks of a diffuse marketplace. Irrespective of the specific outcomes, debates of this sort should be welcomed and encouraged.

g) EPR Schemes and other economic instruments.

Producer responsibility is one of the market stimulants for recycled plastic. Yet current responsibility schemes arguably achieve limited success in their ostensible purpose - completing the true feedback loop from recyclers to producers. Arguably a key reason is that quantitative targets and drivers have been the name of the game to date. It is certainly possible to revise EPR schemes or otherwise influence EPR organisations to engage on quality as well as cost / volume considerations. 
One purpose of EPR schemes is to remove the financial burden for waste treatment from the public sector. Under the EPR schemes, the funding originates entirely from the producers, although these costs may well be passed on to the customer. Relaxing some of the financial burden, perhaps by making limited amounts of public funding available for approved modes of WEEE (plastics) treatment, might encourage EPR organisations to reconsider their tendering criteria. Alternately, without altering the funding arrangements on the macro-scale, the project could look at the financial flows through the EPR scheme, and how funding flows could be made more contingent upon treatment quality.

A more optimistic / ambitious idea is that producer responsibility obligations could be specifically extended to give producers direct motivation to use recycled plastic in their products and/or increase recyclability (Plastic Zero, 2013a).

Enormous amounts of existing work in the literature (e.g. European Commission, 2012b) assess how EPR and other fiscal instruments have been and could be deployed to influence practice in the sector. For instance, essentially fiscal measures have been paramount in disincentivising landfill. (WEEE) plastics recycling often finds itself in effective competition with incineration; perhaps fiscal instruments could be deployed similarly.

h) (Clarify and share understanding on regulatory issues.

Quality issues in the supply chains for waste plastics are a key factor. For packaging plastics this might mean impurities and unwanted elements in the plastics mix; in the case of WEEE plastics this often signifies hazardous materials - heavy metals and BFRs. Understanding quality is key to progress in this area, and in practice this means clarifying issues in RoHS (in particular) regarding sampling and measurement, the specific implications for practice of the terms Maximum Concentration Value and Homogenous Material, and so on. Further investigations over the benefits and risks associated with End-of-Waste criteria would also be useful. It is by no means automatic that exploiting EoW would be advantageous in the WEEE plastics sector.

\subsection{Potential for Nordic collaboration}

A number of pointers and ideas for pan-Nordic collaboration have emerged from the above analysis, and are largely reinforced by stakeholder input to the project thus far. The general sense is a desire to con- 
solidate fragmented markets. Consolidation could theoretically happen at the level of recyclers, transporters or EPR agents - and even across national boundaries.

At the level of recyclers, it seems clear that the biggest players with an international presence are the most likely to provide innovation and drive quality improvement. Economy of scale combined with relative market stability and predictability could confer considerable advantages. Key large-scale actors suggest that shared markets could be essential for a well-functioning Nordic system. The belief is that the biggest companies need to do business abroad, both within the Nordics and beyond. Stakeholders have suggested that in future there could be 2-3 large centres for plastics recycling in the Nordic region.

Consolidating the market in this way perhaps runs the risk of downward price pressure, to the disadvantage of other actors in the value chain. However, these effects could possibly be counterbalanced or outweighed by the economies of scale, also the possibility of reversing the flow of waste plastics (and value) out of the Nordic region to Europe more broadly. Encouragement from the Nordic authorities, perhaps in the form of transparent incentives but more likely by influencing regulations or obligations, could lead to improved competence throughout all steps of the waste plastics recycling chain. Sharing experience and best practice among actors could enhance quality. However, how readily this could be achieved in practice is not particularly clear. In reality, recyclers are businesses in competition with each other and such collaboration would not be easily forced, and arguably should not be.

It may be more fruitful to examine collaboration and consolidation of the market at the level of EPR organisations. It appears that the territory market with the greatest consolidation at EPR level (Sweden) achieves the best overall levels of recycling, although there is not necessarily a causal link. In principle, there is no reason why EPR responsibility could not be shared between territories and this could afford some economies of scale and efficiency gains, although on this and other issues, the fact that Norway and Iceland remain outside the EU could prove a barrier to progress. Competition regulation may also be relevant here. It is perhaps more realistic for individual territories to re-examine their EPR systems - over which governments do have more or less direct control - and consider the possible effects of consolidation there.

At an even higher level, direct collaboration between national environmental protection agencies in the Nordic region, on the specific issue of WEEE plastics, is entirely feasible. This could encompass discussion on common political strategies with respect to the developing regulatory 
framework. Governmental co-operation could lead to the sponsoring of technical developments - ideas include developing guides for tracing materials and compositions along the value chain, establishing pilot projects for WEEE plastics recycling and the development of technologies. Examination, with a view to harmonisation, of national regulations across the Nordic region should be undertaken.

As recognised in earlier analysis, many EE products are produced outside Europe, and the producers are somewhat remote from the value chain and hard to influence (although importers do bear responsibility). However, design of electronic products often takes place closer to home, and looking at links and information sharing with designers is surely worth pursuing. 


\section{Conclusions}

The WEEE plastics value chains across the Nordic region are worldleading in many respects, and yet are some way from being as effective as they realistically can be. There are a range of human, market-related, organisational, regulatory, legal and technological reasons for this. The organisation of the market, at a number of different levels, appears to be the root of the most significant factors. There are a range of more and less ambitious interventions that could be attempted to effect change.

Governments and NGOs have the potential to directly influence parts of the value chain, but a weak and indirect (at best) influence on other parts. Few of the prospective improvements can be achieved by single actors or small groups acting alone. A recurring theme is the need for collaborative action across a range of different actors in the value chain.

The second stage of the project will further develop and investigate the proposals for improvement outlined in this report. Certain specific questions - with reference to current technological expertise, elements of regulations and their practical implementation, and other issues have emerged during the synthesis of the Part I report, and will be investigated with the stakeholder group at the very beginning of Part II. 



\section{References}

Axion Consulting (2013). "What We Do", http://www.axionconsulting.co.uk/whatwe-do/, accessed January 2014

Bomcheck (2013), "How does Bomcheck manage compliance with RoHS restrictions in China, Korea and Japan?", https://www.bomcheck.net/rohs/ how-does-bomcheck-manage-compliance-with-rohs-restrictions-in-china-koreajapan, accessed January 2014.

ChemSec (2013), “626 Substances of Very High Concern”, http://www.chemsec.org/ what-we-do/sin-list, accessed January 2014.

Darby L., Obara L. (2005), "Household recycling behaviour and attitudes towards the disposal of small electrical and electronic equipment", Resources, Conservation and Recycling, Vol 44, No 1 pp 17-35.

Danish Ministry of Environment (2012), "Greening of Electronics”, Environmental Project No. 1416, http://www2.mst.dk/Udgiv/publications/2012/07/ 978-87-92779-99-1.pdf, accessed January 2014.

DEFRA (2007), "WEEE Plastics Separation Technologies, Final Report: Axion Recycling Ltd.", http://randd.defra.gov.uk/ Document.aspx?Document=WR0202_6320_FRP.pdf, accessed January 2014.

Dimitrakakis E., Janz A., Bilitewski B., Gidarakos E. (2009), “Small WEEE: Determining recyclables and hazardous substances in plastics", J.Hazardous Materials, Vol 161 No. 2-3, pp 913-919.

DPA-System (2014), “WEEE Producer Responsibility Statistics”, http://www.dpa-system.dk/en/WEEE/ProducerResponsibility/Statistics, accessed January 2014.

El-Kretsen (2011), “Our Operations, 2011 http://www.el-kretsen.se/sitespecific/ elkretsen/files/elk_0066_arsrapport_2011_eng_webb.pdf, accessed January 2014.

EPA (2014), "An alternatives assessment for the flame retardant decabromodiphenyl ether (DecaBDE) - Final Report", http://www.epa.gov/dfe/pubs/projects/ decaBDE/deca-report-complete.pdf, accessed March 2014.

EPIC - Environment and Plastics Industry Council (2006), "Report on Separation Trials of Sink Portion of Post-Consumer Mixed Plastics", http://www.plastics.ca/_files/file.php?fileid=itemrbqTCYGfhT\&filename=file_final_ floatation_report.pdf, accessed February 2014.

European Commission (2005), "Frequently Asked Questions on Directive 2002/95/EC on the Restriction of the Use of certain Hazardous Substances in Electrical and Electronic Equipment (RoHS) and Directive 2002/96/EC on Waste Electrical and Electronic Equipment (WEEE)", http://ec.europa.eu/environment/ waste/pdf/faq_weee.pdf, accessed January 2014.

European Commission (2007), "REACH - Registration, Evaluation, Authorisation and Restriction of Chemicals", http://ec.europa.eu/enterprise/sectors/ chemicals/reach/index_en.htm, accessed January 2014.

European Commission (2008a), "Recast of the RoHS Directive", http://ec.europa.eu/environment/waste/rohs_eee/, accessed January 2014. 
European Commission (2008b), "Directive 2008/98/EC on waste (Waste Framework Directive)", http://ec.europa.eu/environment/waste/framework/, accessed January 2014.

European Commission (2012a), "Recast of the WEEE Directive”, http://ec.europa.eu/environment/waste/weee/index_en.htm, accessed January 2014.

European Commission (2012b), "Use of Economic Instruments and Waste Management Performances", http://ec.europa.eu/environment/waste/pdf/ final_report_10042012.pdf, accessed January 2014.

Eurostat (2014), "Waste Electrical and Electronic Equipment", http://epp.eurostat.ec.europa.eu/portal/page/portal/waste/key_waste_streams/ waste_electrical_electronic_equipment_weee, accessed January 2014.

EEregistret (2014), "Produsentregister for elektriske og elektroniske produkter", www.eeregistret.no, accessed January 2014

Greenpeace (2006), "EPR: Extended Producer Responsibility", http://www.greenpeace.org/international/PageFiles/24472/epr.pdf, accessed January 2014.

Hjellnes Consult (2008), “Kartlegging av Produsentansvarsordningene”, Miljøverndepartementet, http://avfallnorge.web123.no/article_docs/ Sluttrapport $\% 20$ produsentansvarsordningene $\% 20-\% 20$ endelig\%20versjon.pdf, accessed January 2014.

Konkurransetilsynet (2013), "Noen må snakke sammen", http://www.konkurransetilsynet.no/no/aktuelt/artikler-og-innlegg/ noen-ma-snakke-sammen/?hl=ee\%20avfall, accessed February 2014

Köhnlechner, R. (2013), “Separation of Black Plastics”, http://forum.bulk-online.com/ showthread.php?25842-Separation-of-Black-Plastics

MBA Polymers (2013), "MBA Polymers Austria Kunstoffverarbeitung GmbH”, http://www.mbapolymers.com/home/ mba-polymers-austria-kunstoffverarbeitung-gmbh, accessed January 2014.

Miljødirektoratet (2014), "Product Regulations, Chapter 2", http://www.miljodirektoratet.no/no/Regelverk/Forskrifter/ Regulations-relating-to-restrictions-on-the-manufacture-import-export-sale-anduse-of-chemicals-and-other-products-hazardous-to-health-and-the-environmentProduct-Regulations/Chapter-2-Regulated-substances-preparations-andproducts/, accessed January 2014

Naturvårdsverket (2014), "WEEE statistik 2008-2012”,

http://eeb.naturvardsverket.se/Global/Statistik/WEEE\%20statistik.pdf, accessed January 2014.

ICIS (2011), "Petrochemicals: Challenges in the styrene market", http://www.icis.com/resources/news/2011/12/05/9513409/ petrochemicals-challenges-in-the-styrene-market/, accessed January 2014.

IHS (2012), News Releases, http://press.ihs.com/press-release/ commodities-pricing-cost/after-major-downturn-global-demand-polycarbonategrowing-agai, accessed January 2014.

IVL (2012), "Kartläggning av plastavfallsströmmar i Sverige”, SMED Report No. 108.

KLIF (2013), "Hazardous Substances in plastic materials", http://www.miljodirektoratet.no/old/klif/publikasjoner/3017/ta3017.pdf, accessed January 2014. 
JRC (2013), Joint Research Centre of the European Commission, "End-of-waste criteria for waste plastic for conversion: Technical Proposals, Final Draft Report", http://susproc.jrc.ec.europa.eu/activities/waste/documents/

EoWPlasticsfinalDrepMar2013WEB.pdf, accessed January 2014.

Mepex (2013), "Increased Utilization of the Resources in Plastics Waste”, The Norwegian Climate and Pollution Agency Ministry for the Environment (2013), "Brominated Flame Retardant Research A Pilot Study of E-waste Plastic Sorting in New Zealand", http://www.mfe.govt.nz/publications/waste/

bromide-flame-retardant-waste/pilot-study-e-waste-plastic-sorting.pdf, accessed January 2014.

Ministry for the Environment and Natural Resources (2013): Landsáætlun um meðhöndlun úrgangs 2013-2024. (Waste Management Plan for Iceland 20132024). http://www.umhverfisraduneyti.is/media/PDF_skrar/ Landsaaetlun-2013-2024-(utgafa).pdf, accessed January 2014.

Norden (2013), "Resource efficient recycling of plastic and textile waste" (2013), Preliminary report prepared for the Nordic Council of Ministers - Project number: 2012.05.21.

Norden (2014), "Improvements in existing collection and recycling systems for plastic waste from households and other MSW sources - Report 1", Preliminary report prepared for the Nordic Council of Ministers.

Ongondo, F.O. and Williams, I. D. (2011) "Mobile phone collection, reuse and recycling in the UK". Waste Management, vol 31, No 6, pp 1307-1315.

PCI (2013), "Acrylonitrile and Derivatives World Supply / Demand Report 2013", http://www.pci-acrylo.com/dox/PCI\%20Acrylonitrile\%20Supply\% 20Demand\%20Report\%202013.pdf, accessed January 2014.

Planmiljø (2006), "Eksport af brugte el-produkter som affald eller som second-hand produkter [Export of used elctrical eqiupment as waste or as secons hand products]". MPU alm. del - Bilag 166.

Planmiljø for the Danish Environmental Protection Agency.

Plastic Zero (2013a), "Action 4.1 - Market Conditions for Plastics Recycling”, Report, www.plastic-zero.com/media/30825/

action_4_1_market_for_recycled_polymers_final_report.pdf, accessed January 2014 .

Plastic Zero (2013b), “Action 4.1 - Annexes”, http://www.plastic-zero.com/media/ 38128/Annexes\%20-\%20Action\%204.1\%20report.pdf, accessed January 2014.

Plastics Europe (2011), "Plastics - The Facts, 2010"

http://www.plasticseurope.org/documents/document/

20101006091310-final_plasticsthefacts_28092010_lr.pdf, accessed January 2014.

Plastics Europe (2013), "Plastics - The Facts, 2013",

http://www.plasticseurope.org/Document/plastics-the-facts-2013.aspx?FolID=2, accessed January 2014.

Samsonek, J. and F. Puype (2013). "Occurrence of brominated flame retardants in black thermo cups and selected kitchen utensils purchased on the European market." Food Addit Contam Part A Chem Anal Control Expo Risk Assess, vol 30, No 11, pp 1976-1986.

Schlummer, M., Maurer, A. (2012), "Method for separating differently additivated polymer components and use thereof", US Patent 8225937, granted 2012.

Sicon Technology (2014), "Polyfloat”, http://sicontechnology.com/ recycling-verfahren/plastic-recycling/polyfloat/, accessed January 2014. 
Stena Technoworld (2013), "IT Equipment and Small Appliances", http://stenatechnoworld.com/Treatment-processes/IT-small-appliances/, accessed January 2014.

Stenvall, E., Tostar, S., Boldizar, A., R.StJ.Foreman, M., Moller, K. (2013), "An analysis of the composition and metal contamination of plastics.

from waste electrical and electronic equipment (WEEE)", Waste Management, vol 33, pp 915-922.

Toppila, A. (2011). "Jätehuollon tuottajavastuun jätevirrat. 2011. Esimerkkinä Sähkö- ja elektroniikkalaitteet sekä kannettavat paristot ja akut”. Master's thesis, University of Jyväskylä.

UNEP (2010), "Technical Review of the Implications of Recycling Commercial Pentabromodiphenyl Ether and Commercial Octabromodiphenyl Ether",

http://chm.pops.int/Portals/0/

download.aspx?d=UNEP-POPS-POPRC.6-2-Annex.English.pdf, accessed March 2014.

Wäger, P., Schluep, M., Müller, E. (2010), " RoHS substances in mixed plastics from Waste Electrical and Electronic Equipment", Final Report, EMPA,

http://new.weee-forum.org/system/files/documents/

rohs20in20mixed20plastics_empa_final_2010200920171.pdf, accessed January 2014.

WRAP (2011), "Separation of Mixed WEEE Plastics", http://www.wrap.org.uk/ sites/files/wrap/Separation\%20of\%20mixed\%20WEEE\%20plastics\% 20-\%20Final\%20report.pdf, accessed January 2014.

WRAP (2013a), "WEEE Plastics: Indesit closed-loop recycling trial”, http://www.wrap.org.uk/content/ weee-plastics-indesit-closed-loop-recycling-trial, accessed January 2014.

WRAP (2013b), "Demonstration of using recycled content from UK WEEE plastics in electrical products", http://www.wrap.org.uk/sites/files/wrap/ Demonstration\%20of\%20recycled\%20content\%20in\%20electrical\% 20products\%20summary\%20report.pdf, accessed January 2014.

Ymparisto.fi (2014), "Sähkö- ja elektroniikkalaiteromun keräys ja käsittely”, http://www.ymparisto.fi/download/noname/\%7BD99231A3-00D5-4E01A078-06F2ADCDDB35\%7D/74681, accessed January 2014. 


\section{Sammendrag}

Denne rapporten oppsummerer Del I i prosjektet "Nordic plastic value chains, Case WEEE (Waste Electric and Electronic equipment)", som er initiert av Nordisk Avfallsgruppe (NAG). Rapport for Del 2 kommer at publiceres når projektet er klart i december 2014. Rapporten analyserer verdikjeder for WEEE plast i Norden og konkluderer med at de, til tross for være i front internasjonalt, likevel har betydelige potensial for forbedringer. Ca 400000 tonn WEEE blir årlig samlet inn i Norden. Av dette utgjør 70000 tonn plast, hvorav mindre enn 20000 tonn blir resirkulert. Små husholdningsapparater (Small Domestic Appliances (SDAs)), som har hovedfokus i denne studien, utgjør totalt 188000 tonn av totalt WEEE og 38000 tonn innsamlet plast (hovedsaklig akrylinitril butadien styren, polystyren and polypropylen). Miljøfarlige materialer som ulike metaller og, i større grad, bromerte flammehemmere, er utfordrende i WEEE plast. TV'er og skjermer er de mest utbredte kildene til miljøfarlige materialer.

Plast i WEEE er relativt enkel å separere fra de andre materialene, det finnes en veletablert teknologi for dette. Kostnadene for slike anlegg er dog betydelige, noe som krever store volumer avfall gjennom anleggene. I prinsippet finnes det store sluttbrukermarkeder for resirkulert WEEE, men i praksis er bildet mer komplisert. Lukkede resirkuleringssystemer er foreløpig svært begrenset, og markedet for resirkulert plast er konkurranseutsatt. Markedet preges av usikkerhet rundt det resirkulerte materialets kvalitet, spesielt når det gjelder innhold av miljøfarlig materiale, samt konkurranse fra resirkulert plast fra mer etablerte kilder, som for eksempel plastemballasje.

EU direktivene WEEE (Waste Electric and Electronic equipment), RoHS (Restriction of Hazardous Substances Directive) and REACH (Registration, Evaluation, Authorisation and Restriction of Chemicals) utgjør det sentrale rammeverket for innsamling og resirkulering av WEEEavfall, i tillegg til EU's utkast til End-of-waste criteria for plastics.

Implementeringen av innsamling av WEEE (hvem har ansvar for hva) er forskjellig i de ulike land ved at markedet er oppdelt på ulike måter gjennom verdikjeden. Innsamling og transport av avfall er relativt konkurransekraftig, mens behandling av plast er dette i mye mindre grad. Markedssegmentering er positivt med hensyn på press på kostnade- 
ne/prisene, men mindre positivt når det gjelder plastens kvalitet. Det viktigste, og kanskje vanskeligste, aspektet for økt materialgjenvinning er å oppmuntre elektronikkprodusenter til å designe varer som er lett å resirkulere. Dette kan kanskje gjøres gjennom subsidier, sertifikatordninger og/eller ved å vurdere aktuelle krav til offentlige innkjøp - for å $ø$ ke etterspørselen av denne type produkter .

Denne rapporten er en del av de Nordiske Statministrenes gønn vekst strategi: "The Nordic Region - leading in green growth". For mer info, se internet magasinet "Green Growth the Nordic Way" at www.nordicway.org eller på www.norden.org/greengrowth 


\section{Annex A: Reference / Stakeholder Groups}

The following individuals formed the reference group for the project and were approached for interview input. Not all provided input at this stage.

\begin{tabular}{ll} 
Organisation & Representative(s) \\
\hline Danish EPA (Miljøministeriet, Miljøstyrelsen ) & Lerche Dorte Bjerregaard \\
DCR Miljø & Karsten Kronborg; Allan Højer \\
EIRetur & Henrik Jacobsen \\
HJ Hansen & Benjamin Wædeled \\
STENA & Morten Rolighed Larsen \\
Uniscrap & Anne-Lise Dyhl \\
IRF (Interkommunali Renovationsfelagsskapurin L/F) & Poul Andrias Joensen \\
Ekokem Oy Ab & Camilla Wiik \\
Elker Ltd & Sakari Hietala \\
Kuusakoski Ltd & Ms. Leena Tuominen \\
Regional environmental authority (Pirkanmaa Regional Environment Centre) & Mr. Teemu Virtanen \\
KANUKOKA (De Grönlandske Kommuners Landsforening) & Pétur Haukur Guðmundsson \\
Icelandic Recycling Fund (IRF) & Ólafur Kjartansson \\
National Association of Local Authorities (Iceland) & Lúðvík E. Gústafsson \\
Sorpa waste management / FENÚR (Icelandic Waste Association) & Ragna I. Halldórsdóttir \\
Elretur & Stig Ervik \\
Miele AS & Thor Hermansen \\
Norsk Gjenvinning Plast AS & Ragnar Suggelia \\
Stena Recycling AS & Snorre Kolseth \\
El-Kretsen & Martin Seeger \\
Stena Technoworld & Mats Torring \\
Stena Weee & Sverker Sjölin \\
Swedish Plastics Organisation & Lena Lundberg \\
Mikael Lekbeck & SIMS Recycling \\
Torbjörn Källberg & Kuusakoski Sverige \\
Lena Lundberg (Innovations- och kemiindustrierna) & IKEM \\
Anne-Marie Johansson & Kemikalieinspektionen \\
Mepex Consulit AS/ European Association of Plastics Recycling and & Peter Sundt \\
Recovery Organisations & \\
\hline & \\
\hline
\end{tabular}


The following individuals gave specific input to the WEEE Plastics project by taking part in one of the relevant parallel sessions at the project workshop.

\begin{tabular}{|c|c|}
\hline Organisation & Representative(s) \\
\hline Oslo kommune,Renovasjonsetaten & Rasmus Andersen \\
\hline Elektrogjenvinning Norge AS & Hans Andreas Bakke \\
\hline Elretur AS & Stig Ervik \\
\hline Icelandic Recycling Fund & Iris Gunnarsdottir \\
\hline Lassila \& Tikanoja plc & Janne Hannula \\
\hline Revac AS & Glenn Hansen, Jørn Svinsholt \\
\hline PolymerTrade AS & Per Haakonsen \\
\hline Återvinningsindustrierna & Viveke Ihd \\
\hline Swedish Plastics Industry Association & Frantzeska Papadopoulou \\
\hline BIR Privat & Barbro Relling \\
\hline IKEA Norway & Nina Schefte \\
\hline Renas AS & Laila Borgen Skaiaa \\
\hline Mepex Consult AS & Olav Skogesal \\
\hline Ålesundregionen Interkommunale Miljøselskap IKS & Øystein Solevåg \\
\hline PVC Forum Norge & $J \varnothing r n$ Sundbø \\
\hline DAKOFA & Inge Werther \\
\hline Ekokem Oy AB & Camilla Wiik \\
\hline
\end{tabular}




\section{Annex B: Meeting Notes from Nordic Workshop}

\subsection{Parallel sessions - Project 2}

The first of the two parallel sessions had 14 participants divided in three group tables. In the second parallel session 9 participants was involved. Participation included representatives from recycling sector, public sector, business federations and research. The parallel work session was structured so that the first parallel session focused on identifying the most important challenges in WEEE recycling, while the second parallel session focused on solutions to the challenges identified in the first session, although both sessions included discussions on both challenges and solutions. In the first session the following question was basis for the group discussion:

In your experience, which are the most important challenges for the Nordic WEEE plastic recycling? Prioritise and describe two important challenges!

In the group discussions and in plenary the following challenges were identified as the most important:

1. Toxic compounds in plastic and lack of clear regulations on how to measure these.

The large amount of WEEE-products containing brominated flameretardants (BFRs) and other compounds that are unwanted in recycled plastic products represent a big challenge for improved WEEE plastic recycling. This seems to be strengthened by the fact the rules and regulations are reported to be unclear with regards to how maximum allowed values are to be applied and measured. There are no clear rules for the chemical testing of recycled plastics. Are negative results on a few granulate/ pellets samples meaning that the whole batch is sent to incineration? This uncertainty makes it difficult to attract investments due to the lack of predictability for the sector.

Possible solutions: The high amount of WEEE products containing compounds that are not unwanted in recycled plastics needs to be tack- 
led at the producer stage. This is difficult as most WEEE products are produced in Asia and producers are not bound by the same regulatory standards or the same incentives and motivations as Nordic actors. Among the suggestions in the workshop was the introduction of the same regulatory standards to import of products as that of export of waste generated by the same product. Currently, WEEE-products face fewer restrictions on import than as recycled materials for export. By mirroring export waste regulations with the product import regulations the Nordic countries can influence the use of chemical compounds so that they don't enter into the value chain in the first place. More closed loop recycling as is the case with refrigerators was also mentioned.

On the issue of regulations a Nordic harmonisation on plastic waste recycling is also needed to create a pan-Nordic market for recycling of WEEE-waste. In this context Norwegian regulations are perceived as stricter than those of their neighbouring EU-member state countries. That means striking sensible compromises. Paramount to this work is improved dialogue between recyclers, lawmakers and producers.

2. Complicated products and components making it difficult to disassemble and sort WEEE products.

Small domestic appliances (SDAs) are increasingly technical and complicated which means that they are difficult to disassemble. In addition to the complexity of plastic components there is also the underlying issue of other precious hard metals and other components that often are toxic and do not as of yet have systems for recycling in place.

Possible solutions: By representatives in the second parallel session the challenge of complex WEEE-products is mostly perceived as a challenge of WEEE-products in the general recycling- and waste stream and not to the specialised actors of WEEE-recycling. The specialised actors has the technology and know-how required to separate the recyclable plastic also from complex SDA's. Increased traceability of plastic parts and their components was also mentioned as a possible solution, but others stated that sorting technology is so developed that different plastics types can be determined at recycling stage. However, this technology is only available to the bigger recyclers. 
3. Lack of interest and knowledge in the recycling industry about plastic recycling and the potential value of recycled plastics.

Significant parts of the recycling industry remain unaware of the value of recycled plastics. Large part of the industry is conservative and still oriented towards recycling of metal, paper and glass. That means that a certain amount of WEEE-products never enter the plastic recycling value chain and that few operators are established in the market.

Possible solutions: There is a need to communicate the value of plastic waste in a clearer way so that more recyclers enter the plastic waste value chain. This will be the shared responsibility of public sector and already established actors. WEEE business has knowledge on treatment of plastic waste and need to be better at sharing this in the wider recycling industry. Looking at options for raising the bar on incineration of WEEE-plastics is also important in order to increase attractiveness of recycling.

\section{Market situation.}

The demand for recycled plastics is not matching the supply of recycled plastics. This is particularly so for Europe. After China's "green fence" prices have dropped as demand in China has dropped. The few market options make incineration a tempting option. Furthermore, the lack of shared operational standards and quality ratings in the business itself is also causing difficulties as the market finds it difficult to know what to ask for.

Possible solutions: There are differences to what degree market challenges exist with regards to WEEE recycled plastics. Some of the plastic, especially polystyrene derived from white goods (refrigerators etc) has a well functioning market. This is partly due to a more closed recycling loop (separated from other WEEE products). Possible ways of increasing market demand are green certificates or subsidies to producers using recycled plastics, and a more active role by public sector itself in procurement processes by procuring products with recycled plastics. An improved dialogue between recyclers and producers to highlight the positive aspects of recycled plastics is also here incremental in driving the demand for recycled WEEE plastics.

Other important issues discussed during the parallel sessions were: Product groups.

The project sought input on what product groups to focus on in its continued work. By the participants in the parallel session there was an almost unilateral support for small domestic appliances (SDA) to make 
the case for further analysis. SDA's are growing in volume and are heterogeneous with regards to components and therefore most challenging.

Summary: Ole Jørgen Hanssen and Kari Anne Lyng from Østfoldforskning summarised by saying that the challenges and solutions discussed in the two parallel sessions corresponded well with the work undertaken in the project so far. The project will now use the insights from the discussions in its further work focusing on SDA's. 
Ved Stranden 18

DK-1061 Copenhagen K

www.norden.org

\section{Plastic value chains}

This project identifies thousands of tonnes per annum of potential enhanced plastics recycling from Nordic electronic waste. Plastics recycling does not always feature prominently in waste treatment. Recycling is technologically viable although the market and economic landscape is challenging. Easy export markets for waste plastic are largely closed and near-source treatment is increasingly needed. Concerns include issues of quality and worries about hazardous materials. Positively engaging electronics producers - beyond the bare punitive requirements within extended responsibility schemes - is a crucial driver for further developments.

The report is part of the Nordic Prime Ministers' overall green growth initiative: "The Nordic Region - leading in green growth". Read more in the web magazine "Green Growth the Nordic Way" at www.nordicway. org or at www.norden.org/greengrowth

The report for Part 2 will be published in December 2014.

TemaNord 2014:542

ISBN 978-92-893-2802-9

ISBN 978-92-893-2803-6 (EPUB)

ISSN 0908-6692
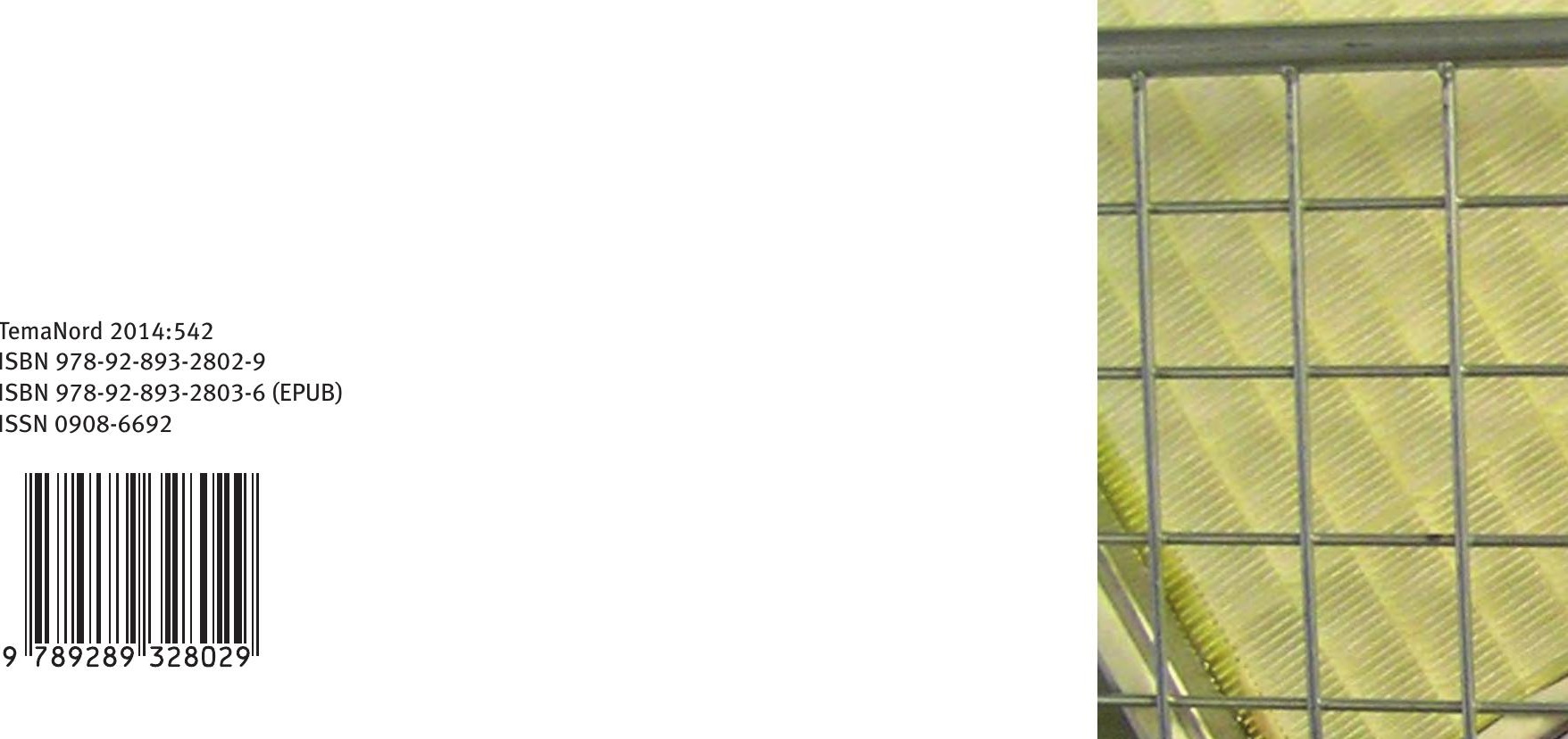